\title{
TÜRK HUKUKUNDA KORUYUCU AİLE SÖZLEŞMESİ VE KORUYUCU AİLE İLE ÇOCUK ARASINDAKİ HUKUKİ İLIŞKİNINN DEĞERLENDİRILMESİ
}

\author{
Dr. Öğr. Üyesi Ayşe Nur KILINÇ *
}

Öz

Türkiye'de son yıllarda çocuk koruma sisteminde koruyucu aile bakımı teşvik edilmektedir. Resmi istatistiklere göre, korunmaya ihtiyacı olan çocukların koruyucu aile yanına yerleştirilme oranı artmıştır. Bu artışa paralel şekilde, koruyucu aile müessesesi ile ilişkili uyuşmazlıkların artması beklenmektedir. $\mathrm{Bu}$ çalışmada koruyucu aileyle yanına yerleştirilen çocuk arasındaki ilişkinin hukuken değerlendirilmesi amaçlanmıştır. Türk hukukunda çocuğun bakımında asli sorumluluk velâyet hakkı sahibi ana ve babanındır. Ancak çocuğun korunması amacıyla hâkim kararıyla ana ve babasından alınarak aile yanına yerleştirilmesi de mümkündür. Koruyucu aile sözleşmesi, bu çocuğun koruyucu aile yanına yerleştirilmesini konu edinen ve Aile, Çalışma ve Sosyal Hizmetler İl Müdürlüğü ile koruyucu aile arasında imzalanan sözleşmedir. Çocuk, bu sözleşmeyle koruyucu ailenin "ev düzenine" tabi olur. Bu ilişki kural olarak "özel hayata sayg1 gösterilmesi hakkı" kapsamında korunmaktayken; istisnaî olarak "aile hayatına saygı gösterilmesi hakkı" kapsamında korunur. Yine bu istisnaî hâllerde, koruyucu aileyle çocuğun birbirinin hukukî anlamda "yakını" sayılması gerekir.

* $\quad$ Dr. Öğr. Üyesi, Ankara Hacı Bayram Veli Üniversitesi Hukuk Fakültesi Medeni Hukuk Ana Bilim Dalı, Ankara, Türkiye| Asst. Prof., Ankara Hacı Bayram Veli University, Faculty of Law, Department of Civil Law, Ankara, Turkey.

囚ayse.kilinc@hbv.edu.tr• ORCID 0000-0001-8190-6557

Atıf Şekli | Cite As: KILINÇ Ayşe Nur, “Türk Hukukunda Koruyucu Aile Sözleşmesi ve Koruyucu Aile ile Çocuk Arasındaki Hukuki İlişkinin Değerlendirilmesi", SÜHFD., C. 28, S. 3, 2020, s. 1217-1261.

Intihal | Plagiarism: Bu makale intihal programında taranmış ve en az iki hakem incelemesinden geçmiştir. I This article has been scanned via a plagiarism software and reviewed by at least two referees. 


\title{
Anahtar Kelimeler
}

Koruyucu Aile - Korunmaya İhtiyacı Olan Çocuk - Korunma Kararı

- Ev Düzeni • Özel Hayata ve Aile Hayatına Saygı Gösterilmesi Hakkı

\section{THE FOSTER CARE CONTRACT UNDER TURKISH LAW AND AN EVALUATION OF THE LEGAL RELATIONSHIP BETWEEN THE FOSTER PARENTS AND THE FOSTER CHILD}

\begin{abstract}
Recently, the foster care has been promoted in Turkish child protection system. Accordingly, it's expected that the number of the legal conflicts regarding this issue will increase. This article aims at evaluating the legal nature of the relationship between the parties. Under Turkish law, the parents are responsible for the care of their children. Only when it's necessary, the children in need of protection are placed into the foster care by the courts. Thereupon the foster care contract's signed between the foster parents and the authorities. It's concluded that as the foster child is within the household, the foster parents are the head of the household. Also, as a rule, this relationship is subject to "the right to respect for private life", but in only exceptional cases it is subject to "the right to respect for family life". Finally, this relation between the parties might be considered as a close personal relationship in terms of law.
\end{abstract}

\section{Key Words}

Foster Parents $\bullet$ Children in Need of Protection - Protection Order $\bullet$ Authority within the Household $\bullet$ The Right to Respect for Private and Family Life

\section{GİRIŞ}

Çağdaş hukuk sistemlerinde çocuğun ana ve babasıyla yaşama hakkı güvence altına alınmıştır. Bununla birlikte ana ve babanın çocuğu ihmal ettiği, sömürdüğü yahut şiddete maruz bıraktı̆̆ı hâllerde çocuğun aile içinde kalması üstün yararına aykırı olur. Bunun yanında çocuğun ana ve babasının belli olmaması, onlar tarafından terk edilmesi gibi sürekli olarak aile ortamından yoksun kaldığı hâller de olabilir. Çocuk Haklarına Dair Birleşmiş Milletler Sözleşmesi' ${ }^{1}$ nin tarafı olan çağdaş devletlerin, bu hâllerde çocuğun korunmasına yönelik tedbirleri alıp teşkilatı kurma görevi bulunur. Sözleşmeyi imzalayıp onaylayan

Sözleşme için bkz. https://www.ohchr.org/Documents/ProfessionalInterest/crc.pdf , s.e.t. 22.04 .2020 . 
Türkiye Cumhuriyeti'nin Anayasası'nda da her çocuğun korunma ve bakımdan yararlanma hakkı ile yüksek yararına açıç̧a aykırı olmadıkça, ana ve babasıyla kişisel ve doğrudan ilişki kurma ve sürdürme hakkı güvence altına alınmıştır (m. 41).

Bilimsel araştırmalarda çocuğun bakımında aile ortamının en uygun yer olduğu kanıtlanmıştır². Bu sebeple çocuğun öncelikle ana ve babası yanında korunmasına önem verilir. Çocuğun devlet korumasına alınması gerektiğinde ise, koruyucu aile gibi aile temelli bakım hizmetleri kurum bakımına tercih edilir ${ }^{3}$. Oysa korunmaya ihtiyacı olan her çocuğun değil; özellikle güven ve saygı temelinde uzun süreli bağlanma ihtiyacı içinde olan küçük yaş grubundaki (özellikle üç-beş yaş altı) çocukların koruyucu aile yanına ya da aile benzeri ortamlara yerleştirilmesi önemlidir. Zira bu çocuklar açısından kurum bakımı uzun dönemde topluma uyum sağlamayı güçleştirirt ${ }^{4}$ Öyleyse çocuk koruma sisteminde koruyucu aile ile kurum bakımı birbirini tamamlayan iki sütundur. Her iki bakıma uygun farklı çocuklar vardır.

2 Akyüz, Emine: "Velâyet, Çocuğun Korunması ve Koruyucu Aile Hizmeti", Koruyucu Aile, Evlat Edinme Hizmetleri ve Ruh Sağlığı, (Editör: Erol, Neşe), Ankara 2008, s.108. 2004 yılında Ankara'da 6-17 yaşlarındaki çocuklar üzerinde yapılan bir çalışmada ailesi yanında yaşayan çocuklarda davranış sorunu görülme sıklığının \%9,7, koruyucu aile yanındakilerde \%12,9 ve kurum bakımındakilerde ise \%43,5 olduğu tespit edilmiştir. Kurum bakımından koruyucu aileye geçiş olumludur (Üstüner, Seval/Erol, Neşe/Şimşek, Zeynep: "Koruyucu Aile Bakımı Altındaki Çocukların Davranış ve Duygusal Sorunları", Çocuk ve Gençlik Ruh Sağlığ1 Dergisi, C.12, Sa.3, 2005, s.133, 138-139). Bu iki bakımın uzun dönemli sonuçları incelendiğinde koruyucu aile bakımından yararlananların eğitim ve hayat başarısı daha yüksek bulunmuştur (Erol, Neşe/Şimşek, Zeynep: "Korunma Gereksinimi Olan Çocuklar; Kurum Bakımı ve Koruyucu Aile Sistemi", Koruyucu Aile, Evlat Edinme Hizmetleri ve Ruh Sağlığı, (Editör: Erol, Neşe), Ankara 2008, s. 151-152).

3 Konanç, Esin: “Türk Hukuk Sisteminde Çocuğun Korunması", Türkiye'de Çocuğun Durumu, Ankara 1989, s.21; Akyüz, 109; Karataş, Ceylan Pınar: “Aile Yaninda Hizmet", Sosyal Hizmet, 2018/I, Ocak Haziran 2018, s. 48.

4 Çocuk Hakları Komitesi, Genel Yorum No. 7 (2005) Erken Çocukluk Döneminde Çocuk Haklarının Uygulanması için bkz. Çocuk Hakları Komitesi Genel Yorumları, s.29. Diğer taraftan araştırmalara göre korunmaya ihtiyacı olan ergenler açısından ne koruyucu aile yanına ne de büyük bakım kurumlarına yerleştirme olumludur (Çocuk Hakları Komitesi, Genel Yorum No. 20 (2017) Ergenlikte Çocuk Haklarının Uygulanması için bkz. Çocuk Hakları Komitesi Genel Yorumları, s. 23). 
Somut olayda çocuğun yüksek menfaati hangi bakım türünü gerektiriyorsa o tercih edilmelidir ${ }^{5}$.

Son zamanlarda Türkiye'de de küçük yaşlardaki korunmaya ihtiyacı olan çocukların topluma kazandırılabilmesi için, koruyucu aile müessesesinin tanıtımı yapilmakta ve toplum koruyucu aile olmaya özendirilmektedir. Zira Çocuk Haklarına Dair Sözleşme'nin tarafı olan Türkiye de, AB üyesi devletlerde olduğu gibi ${ }^{6}$, çocuk koruma sistemini sözleşmedeki ilkelere uygun şekilde geliştirmekle yükümlüdür. Resmi istatistiklere göre Türkiye'de 2015 yılında korunma kararlı çocukların \%26,7'si koruyucu aile yanına yerleştirilmişken; 2018 yılı itibariyle hakkında korunma kararı alınan 20.682 çocuktan 6.468'i (\% 31,2'si) bu bakımdan yararlandırılmıştır ${ }^{7}$. Aile Çalışma ve Sosyal Hizmetler Bakanlığı'nın 2020 yılının şubatında yaptığı bir açıklamaya göre, Türkiye' de 6.015 koruyucu ailenin yanında 7.312 çocuk bulunmaktadır8. $\mathrm{Bu}$ gelişmeler, Türkiye ve korunma kararlı küçük yaştaki çocuklar bakımından olumludur. Bu gelişmelere paralel şekilde, Türkiye'de 2015 yılından itibaren sosyal hizmetler, hukuk, eğitim ve öğretim, psikoloji, psikiyatri ve ev ekonomisi gibi disiplinlerde koruyucu aileye ilişkin çalışmalar da artış göstermiştir?.

Çocuk koruma sistemindeki gelişmeler neticesinde koruyucu aileyle ilgili hukukî uyuşmazlıkların artması muhtemeldir. Bu çalışmada doktrindeki görüşlerden hareketle koruyucu aile sözleşmesinin hukukî

Koşar, Nesrin G.: “Türkiye'de Çocuk Refahı Hizmetlerinin Dünü”, Koruyucu Aile, Evlat Edinme Hizmetleri ve Ruh Sağlığı, (Editör: Erol, Neşe), Ankara 2008, s. 9,14.

6 Avrupa çocuk hakları hukuku, büyük ölçüde Çocuk Haklarına Dair Birleşmiş Milletler Sözleşmesini esas alır. Nitekim AB üyesi devletlerin tamamı bu sözleşmeyi onaylamıştır. Avrupa Birliği de kendi yetki alanına giren konularda bu sözleşmedeki ilke ve hükümlere bağlı kalmalıdır (Çocuk Haklarıyla İlgili Avrupa Hukuku El Kitabı, Avrupa Birliği Temel Haklar Kurumu ve Avrupa Konseyi, 2015, s. 25-26).

7 https://www.ailevecalisma.gov.tr/tr-tr/istatistikler/aile-ve-sosyal-politikalaralanindaki-istatistikler/cocuk-hizmetleri-istatistikleri/, s.e.t. 15.04.2010.

8 https://www.ailevecalisma.gov.tr/tr-tr/haberler/bakan-selcuk-koruyucu-ailetemelli-cocuk-koruma-sistemi-calistayi-25-26-subat-ta-duzenlenecek/, s.e.t. 06.05.2020.

9 Aydoğdu, Fatih: “Türkiye'de Koruyucu Aile Uygulaması ile İlgili Yapılmış Lisansüstü Tezlerin Değerlendirilmesi”, ISSSJ, C.5, Sa.53, 2019, s. 7487-7488. 
niteliği belirlenmekte, özellikle koruyucu aileyle yanındaki çocuk arasındaki hukukî ilişki değerlendirilmeye çalışılmaktadır. Bu amaçla aşağıda önce koruyucu aile müessesesine ilişkin mevzuat ortaya konulmaktadır.

\section{TÜRK HUKUKUNDA KORUYUCU AİLE MÜESSESESINNE İLIŞKİN MEVZUAT}

Türk hukukunda çocuk koruma sistemi, çağdaş sistemlerdeki gibi, uluslararası sözleşmeler ve yasalarla düzenlenmiştir ${ }^{10}$. Bu bağlamda önce Çocuk Haklarına Dair Sözleşme'nin taraf devletlere bu müesseseye yönelik hangi yükümlülükleri yüklediği incelenmelidir. Bu Sözleşme, Türkiye tarafından 14 Eylül 1990 tarihinde imzalanmış, 9 Aralık 1994 tarihinde çekince koyularak onaylanmış ${ }^{11}$ ve Anayasa m. 90'a göre iç hukuk normu hâlini almıştır ${ }^{12}$.

Çocuk Haklarına Dair Sözleşme, çocuğun sürekli veya geçici olarak aile ortamindan yoksun kalması durumunda ya da aile ortamında kalması çocuğun üstün yararına aykırı olduğu hâllerde çocuğa devlet tarafından özel koruma ve yardım sağlanması gereğini vurgular (m. 20/I). Taraf devletler, çocuğun ana ve babası, yasal temsilcisi veya başka kişi tarafından bakımı esnasında fiziksel veya zihinsel şiddete, ihmâle ve cinsel istismar dâhil her tür sömürüye karş1 korunmasina yönelik tedbirleri almakla yükümlüdürler (m. 19). Dolayısıyla Sözleşme taraf devletlere korunma kararlı çocuklar için alternatif bakım sağlama yükümlülügü getirmiştir. Alternatif bakım; koruyucu aile yanına yerleştirme, evlat edinme ya da çocuğun uygun bir kuruma yerleştirilmesi şeklinde gerçekleşebilir. Ancak alternatif bakım esnasında çocuğun yetiştirilmesinde süreklilik korunarak etnik, dini, kültürel ve dil kimliğine saygı gösterilmelidir (m. 20/III).

10 Elmacı, Davut: “Çocuk Korumada Sistem Yaklaşımı”, Prof. Dr. Emine Akyüz'e Armağan Akademisyenlikte Elli Yıl, Ankara 2018, s. 178.

114058 sayılı Onay Kanunu için bkz. 11. 12.1994 tarih ve 22138 sayılı R.G.

12 27.01.1995 tarih ve 22184 sayılı R.G. Ayrıca bkz. Tanrıbilir, Feriha Bilge: Çocuk Haklarının Uluslararası Korunması ve Koruma Mekanizmaları, Ankara 2011, s.6996; Özdemir, Hayrunnisa/Ruhi, A. Cemal: Çocuk Hukuku (Ders Kitabı), 3. Baskı, İstanbul 2019, s. 16-36. 
Sözleşme'de çocuğun görüşlerine saygi gösterilmesi ilkesi de düzenlemiştir (m 12). Sözleşmeyi yorumlama ve taraf devletlerde uygulanışını denetleme yetkisine sahip olan ${ }^{13}$ Çocuk Hakları Komitesi, çocuğun dinlenilme hakkına taraf devletlerce riayet edilmediğini tespit etmiştir. Taraf devletler çocuğun koruyucu aile yanına yerleştirilmesine ilişkin kararlarda olgunluğu ölçüsünde çocuğun görüşlerini dinlemeli ve dikkate almalıdır ${ }^{14}$. Ayrıca Sözleşme'de her çocuğun yüksek yararına aykırı olmadıkça, ana ve babası ile yaşama hakkına sahip olduğu vurgulanmıştır. Sadece kararları yargısal denetime tabi yetkili bir makam tarafından, kanunlara ve usulüne uygun şekilde, çocuğun üstün yararı gerektirdiği için, özellikle çocuğun ana ve babası tarafından ihmal edildiği veya sömürüldüğ̈ hâllerde, çocuğun ana ve babasından alınmasına karar verilebilmelidir (m. 9).

Anayasa m. 41'in "Ailenin korunması" şeklindeki kenar başlığ 2010 yılında "Ailenin korunması ve çocuk hakları" olarak değiştirilmiş ${ }^{15}$ ve çocuk hakları konusundaki temel ilkeler Türkiye'de anayasal güvence altına alınmıştır. Hüküm önceki hâliyle devlete, sadece çocukların korunması için gerekli tedbirleri alıp teşkilatı kurma görevi vermekteydi. Yeni hüküm ise, devleti, çocukları her türlü istismara ve şiddete karşı koruyucu tedbirler almakla yükümlü kılar. Ayrıca her çocuğun korunma ve bakımdan yararlanma, yüksek yararına açıç̧a aykırı olmadıkça, ana ve babasıyla kişisel ve doğrudan ilişki kurma ve sürdürme hakkına sahip olduğunu belirtir.

Çağdaş hukuk sistemlerine paralel şekilde, Türk Medenî Kanunu'nda da çocuğun bakımı, eğitimi ve gelişimini sağlamak ile çocuğu korumak velâyetin kapsamı içindedir (m. 339 vd.). Ana ve baba velâyetten doğan görev, yetki ve haklarını kullanırken çocuğun yararı ilkesini gözetir. Bu yarar gözetilmediğinde, hâkime müdahale yetkisi tanınmıştır ${ }^{16}$. Buna göre çocuğun menfaati ve gelişmesi tehlikeye

\footnotetext{
13 Özdemir/Ruhi, 18. Koruma mekanizmaları için bkz. Tanrıbilir, 66-69.

14 Çocuk Hakları Komitesi Genel Yorum No. 12 (2009) Çocuğun Görüşlerinin Dinlenmesi Hakkı için bkz. Çocuk Hakları Komitesi Genel Yorumları, s. 18.

15 Bkz. 7/5/2010 tarih ve 5982 sayılı Kanun m.4.

16 Dural, Mustafa/Öğüz, Tufan/Gümüş, M. Alper: Türk Özel Hukuku, Cilt III, Aile Hukuku, 15. Baskı, İstanbul 2020, prg.1729; Hatemi, Hüseyin/Kalkan Oğuztürk
} 
düştüğü takdirde, ana ve baba duruma çare bulamaz veya buna güçleri yetmezse hâkim, çocuğun korunması için uygun önlemleri alır (TMK m. $346)^{17}$. Hâkim çocuğun öncelikle ana ve babası yanında korunmasına yönelik hafif önlemleri alır. Çocuk Koruma Kanunu' ${ }^{18 \prime}$ na (ÇKK) göre alınacak tedbirler de çocuğun öncelikle kendi aile ortamında korunmasını sağlamayı amaçlar (m. 5/I). Ancak bu önlemlerden sonuç alınamazsa hâkim, takdir yetkisine dayanarak çocuğu ana ve babadan alarak bir aile yanına veya bir kuruma yerleştirebilir (TMK m. 347) ${ }^{19}$. Benzer bir düzenleme ÇKK'de de bulunmaktadır (m. 5/I (c ) bendi). Bu durumda ana ve babanın velâyet hakkı devam eder; sadece çocuğun oturma yerini belirleme hakkı ile çocuğun bakımı ve yetiştirilmesinde karar verme yetkisi sinırlanır ${ }^{20}$.

Esasen hâkim kararıyla da olsa çocuğun ana ve babasından ayrı yaşamak zorunda kalması gelişimini olumsuz etkiler. Bu sebeple hâkim, çocuğun ana ve babadan alınmasına karar verirken çok dikkatli olmalıdır. Özellikle ana baba bakımının çocuk açısından olumlu yönü kalmadığı ve çocuğun sağlıklı gelişimi için aileden uzaklaşması gerektiği hâllerle sınırlı olarak bu karar verilmelidir ${ }^{21}$. Yine bu karar

Burcu: Aile Hukuku, 6. Baskı, İstanbul 2018, s.197; Akıntürk, Turgut/ Ateş, Derya: Türk Medenî Hukuku Aile Hukuku İkinci Cilt, 22. Baskı, İstanbul 2020, s. 436; Akyüz, 57.

17 Hâkim, bu hâlde, takdir yetkisini kullanarak, ana ve babaya uyarıda bulunup talimat verebileceği gibi uzman bir kişiyi veya kurumu ana babaya veya çocuğa rehberlik yapmak üzere görevlendirebilir. Bkz. Öztan, Bilge: Aile Hukuku, 6. Baskı, Ankara 2015, s.1142-1146; Akyüz, 92-96; Usta, Sevgi: Çocuk Hakları ve Velayet, İstanbul 2012, s.166; Grassinger, Gülçin Elçin: Türk Medeni Kanununda Yer Alan Velâyet Hükümleri Kapsamında Küçügün Kişi Varlığının Korunması İçin Alınacak Tedbirler (MK md. 346, md. 347, md. 348), İstanbul 2009, s.112-123; Dural/Öğüz/Gümüş, prg.1731; Akıntürk/Ateş, 436.

3.7.2005 tarih ve 5395 sayılı Kanun için bkz. 15.07.2005 tarih ve 25876 sayılı R.G.

19 Hükümde aranan şartlar hakkında bkz. Akyüz, 97-100; Öztan, 1146-1152; Grassinger, 142-146. Ana ve babanın çocuğu okula göndermeyerek ağır işlerde çalıştırmaları, çocuk hasta olduğu hâlde onu tedavi ettirmemeleri, çocuğu dilenciliğe, hırsızlığa ve uyuşturucu madde satıcılığına veya fuhşa teşvik etmeleri böyle hâllerdendir (Akıntürk/Ateş, 437).

20 Grassinger, 141. Bu hâlde ana ve babanın çocuğu yetiştirme yetkileri ortadan kalkar (Dural/Öğüz/Gümüş, prg.1737).

21 Akyüz, 97; Grassinger, 139. Çocuğun menfaatinin ön plânda tutulması, talilik, tamamlayıcılık ve orantılılık hâkimin göz önünde bulundurması gereken ilkelerdir. 
verilirken görüşünü açıklayabilecek olgunluktaki çocuğun görüşleri dinlenmeli ve dikkate alınmalıdır ${ }^{22}$.

Türk Medenî Kanunu'na göre çocuğun ana babadan alınması gerektiği sonucuna varan hâkim, çocuğun ihtiyaçlarının bir başka aile yanında mı yoksa bir kurumda mı daha iyi karşılanacağını da takdir yetkisine dayanarak belirler ${ }^{23}$. Çocuk Koruma Kanunu'nda ise, çocuk hakkında alınan bakım tedbirlerinin Aile, Çalışma ve Sosyal Hizmetler Bakanlığı (AÇSHB) tarafından çocuğun resmi veya özel kuruluşlara yerleştirilerek gerçekleştirileceği düzenlenmiştir (m. 10). Sosyal Hizmetler Kanunu'nda ${ }^{24}$ (SHK) da hakkında korunma kararı alınmış çocuğun bakımı ve yetiştirilmesinin ya bu Kanuna göre kurulmuş kurumlarda ya da AÇSHB'nin ${ }^{25}$ denetim ve gözetiminde "Koruyucu Aile" tarafından yerine getirileceği düzenlenmiştir (m. 23). Dolayısıyla korunma kararlı çocuğun koruyucu aile yanına mı yoksa kuruma mı yerleştirileceği hususu uygulamada Aile, Çalışma ve Sosyal Hizmetler İl Müdürlükleri'nce belirlenir ${ }^{26}$. Doktrinde bir görüş çocuğun aile yanına yerleştirilmesine karar verildiğinde hâkimin önceliği çocuğun yakın çevresi ve akrabaları arasından uygun bir aileye vermesi gerektiğini ancak çocuğun yakın çevresinde böyle bir ailenin olmaması durumunda

İlkeler hakkında bkz. Öztan, 1136-1139; Grassinger, 98-105; Usta, Çocuk Hakları, $175-176$.

22 Öztan, 1133; Grassinger, 99. Bkz. Çocuk Hakları Komitesi, Genel Yorum No. 14 Çocuğun Yüksek Yararı Hakkının Öncelikli Olarak Dikkate Alınması (Madde 3, Paragraf 3) için bkz. Çocuk Hakları Komitesi Genel Yorumları, s. 20.

23 Akıntürk/Ateş, 437; Akyüz, 100.

24 Bkz. 27.05.1983 tarih ve 18059 sayılı R.G. Kanunun adı “Sosyal Hizmetler ve Çocuk Esirgeme Kurumu Kanunu" iken, 3/6/2011 tarih ve 633 sayılı KHK ile "Sosyal Hizmetler Kanunu" olarak değiştirilmiştir (m.35).

25 Sosyal Hizmetler ve Çocuk Esirgeme Kurumu 633 sayılı KHK ile kapatılmış (Geçici madde 1) ve mevzuatta bu Kuruma yapılan atıflar Aile ve Sosyal Politikalar Bakanlığı'na yapılmış sayılmıştır (m.35). Ancak daha sonra 633 sayılı Kararnamenin adı "Sosyal Hizmetler Alanında Bazı Düzenlemeler Hakkında Kanun Hükmünde Kararname" şeklinde değiştirilmiş (2/7/2018 tarih ve 703 sayılı KHK m. 3) ve bahsedilen 35. madde de yürürlükten kaldırılmıştır. Nihayetinde mevzuatta Çalışma, Sosyal Hizmetler ve Aile Bakanlığına yapılan atıflar Aile, Çalışma ve Sosyal Hizmetler Bakanlığına yapılmış sayılmaktadır (4/8/2018 tarih ve 30499 sayılı R.G.'de yayımlanan 15 sayılı Cumhurbaşkanlığı Kararnamesi m.4).

26 Çocuğun kurum bakımına alındıktan sonra hangi hizmetten yararlanacağı ana ve babası ile yapılacak mesleki çalışma ile belirlenir (Karataş, 65-66). 
koruyucu ailenin AÇSHB tarafından belirlenebileceğini belirtir ${ }^{27}$. Doktrinde diğer görüş ise, ikincil mevzuatın çocuğun koruyucu aile yanına yerleştirilmesine karar verilmesinde idareyi yetkili kılmasını Kanun'a ve Anayasa'ya aykırı bulur' ${ }^{28}$.

Şu hâlde koruyucu aile müessesesinin Türk hukukundaki yasal dayanağını TMK m. 347, ÇKK m. 5/I (c) bendi ile SHK m. 22. ve 23 oluşturur. Ayrıca 1 Sayılı Cumhurbaşkanlığı Kararnamesi'nde AÇSHB'ye bağlı Çocuk Hizmetleri Genel Müdürlüğü'nün görevleri arasında koruyucu aile hizmetlerini koordine etmek sayılmıştır (m. 69)29. Son olarak koruyucu aile müessesesini tüm ayrıntılarıyla düzenleyen “Koruyucu Aile Yönetmeliği ${ }^{30 ”}$ (KAY) yürürlüktedir.

Yukarıda Türk hukukunda koruyucu aileye ilişkin mevzuat kısaca açıklanmaktadır. Korunma kararlı çocuğun koruyucu aile yanına yerleştirilmesi, AÇSHB tarafından uygunluğu belirlenen koruyucu aile ile il müdürlükleri arasında imzalanan koruyucu aile sözleşmesini mahalli mülki amirin onaylamasıyla gerçekleşir (KAY m. 4/I (m) bendi). Aşağıda koruyucu aile sözleşmesinin hukukî niteliği değerlendirilmektedir. Bunun için önce müesseseye ilişkin temel kavramlar açıklanmaktadır.

27 Grassinger, 150-151; Gençcan, Ömer Uğur: Velâyet Hukuku Yargitay Uygulaması, Bilimsel Açıklama ve En Son İçtihatlar, Ankara 2015, s. 89.

28 Usta Sayıta, Sevgi: Türk Hukukunda Çocuğun Koruyucu Aile (Kişi) Yanına Yerleştirilmesi, İstanbul 1996, s.75. Koruyucu aile sözleşmesi, idare ile koruyucu aile arasında imzalanan sözleşmenin çocuk hâkimi tarafından onaylanmasıyla hüküm ve sonuçlarını doğurmalıdır (Usta Sayıta, 77). Yürürlükteki Koruyucu Aile Yönetmeliğinin de yarg1 fonksiyonunu idari fonksiyona dönüştürdüğü ve bunun 1982 Anayasasının 7, 8 ve 9. maddelerine aykırı olduğu sonucuna varılmıştır. Zira koruyucu aileyi seçme, denetleme ile çocuğu koruyucu aileye yerleştirme konusundaki takdir yetkisi hâkime aittir (TMK m.347, ÇKK m. 5/I (c) bendi). Ancak ikincil mevzuat ile bu yetki idareye bırakılmıştır. Kanun ile yargıya verilen yetkinin idare tarafından kullanılmasına imkân tanınması fonksiyon gaspı olup, bu durum kuvvetler ayrılığı ilkesine ve Anayasaya aykırıdır (Doğan, Recep: Bir Koruma Tedbiri Olarak Koruyucu Aile Kurumu ve Koruyucu Aile Yönetmeliği", Ankara Barosu Dergisi, Sa.2, 2013 s.167-168).

$29 \quad$ 10.07.2018 tarih ve 30474 sayılı R.G.

$30 \quad$ 14.12.2012 tarih ve 28497 sayılı R.G. 


\section{KORUYUCU AİLE SÖZLEŞMESINNE İLIŞKINN TEMEL KAVRAMLAR}

\section{A. Koruyucu Aile}

Korunma kararlı çocuğun bakımı ve yetiştirilmesi "Koruyucu Aile" tarafından da yerine getirilebilir. Koruyucu aile bu hizmeti yerine getirirken çocuğun eğitimi ve yetiştirilmesinde kullanılmak üzere AÇSHB'den bir ödeme talep edebileceği gibi bu görevin getirdiği masrafları tamamen kendisi de üstlenebilir.

Türk hukukunda tercih edilen bu terim koruyucu ailenin kapsamını belirlemekten uzaktır. Zira koruyucu aile bir aile olabileceği gibi tek bir kişi de olabilir. Koruyucu aile nitelemesi, koruyucu ailenin mutlaka evli kişilerden olması gerektiği izlenimi uyandırmaktadır ${ }^{31}$. Oysa koruyucu aile ne evli olmak ne de çocuk sahibi olmak zorundadır. Evli olmayan kişi de pekâlâ koruyucu aile olabilir. Nitekim KAY'da koruyucu ailenin "en az temel ana ve baba eğitimleri kapsamında eğitim almış kişi veya aileler" olabileceği belirtilmektedir (m. 4/ I (a), (e), (h), (r), (ş) bentleri). Ancak koruyucu aile olmak üzere başvuranların evli olmaları hâlinde eşleriyle başvurma zorunluluğu bulunur (m. 8/III). Dolayısıyla Türk hukukunda, cinsiyet ayrımı yapılmaksızın, evli olmayan kişilerin koruyucu aile olmak üzere başvurmaları mümkündür.

Koruyucu aile, herhangi bir sebeple ana babası ile yaşayamayan çocuklara, kısa ve uzun süreli bakım ve koruma sağlar ve bu çocukları yetiştirir ${ }^{22}$. Diğer bir deyişle, koruyucu aile, çocuğun ana ve babası yerine ana babalık rolü üstlenir ${ }^{33}$. Ancak çocuğun bu süreçte ana ve babası ile kişisel ilişkisi de kesilmez. Çocuk ile ana babası arasındaki iletişim AÇSHB'nin denetimi ve gözetimi altında devam ettirilir. Zira alternatif bakım modeli olan koruyucu ailenin geçici olması asıldır.

31 Terim eleştirisi için bkz. Sayıta Usta, 21.

32 Usta Sayita, 24; Serdar, İlknur: "Koruyucu Aile", Prof. Dr. Seyfullah Edis'e Armağan, İzmir 2000, s.468; Özdemir Uluç, Fatma: Psiko-Sosyal ve Hukuksal Açıdan Koruyucu Aile Bakımı, Ankara 1997, s. 28; Karatay, Abdullah: “Türkiye'de Koruyucu Aile: Kökenleri, Gelişimi ve Bugünü", Üsküdar Üniversitesi Sosyal Bilimler Dergisi, Sa.5, 2017, s.390.

33 Yazıc1, Ergün: “Türkiye'de Çocuk Koruma Sistemi ve Koruyucu Aile Bakım Yönteminde Yeni Yaklaşımlar", Çankırı Karatekin Üniversitesi İ̈BF Dergisi, C.4, Sa.2, 2014, s.254. 
Nihai amaç sorunlar geçtiğinde çocuğun ana ve babasının yanına dönüşünün sağlanmasıdır ${ }^{34}$. KAY'da farklı koruyucu aile tipleri tanımlanmıştır. Uygulamada çocuğun akrabaları arasında çocuğun gelişimi açısından uygun olduğu düşünülen bir aile varsa koruyucu aile olarak bu aile seçilmektedir ${ }^{35}$.

\section{B. Korunmaya İhtiyacı Olan Çocuk}

Korunmaya ihtiyacı olan çocuk, Türk hukukunda çeşitli kanunlarda açıkça tanımlanmıştır. Bedensel, zihinsel, ahlaki, sosyal ve duygusal gelişimi ile kişisel güvenliği tehlikede olan, ihmal veya istismar edilen ya da suç mağduru çocuklar korunma ihtiyacı olan çocuklardır (ÇKK m. 3/I (a) bendi). Korunmaya ihtiyacı olan çocuk; beden, ruh ve ahlakî gelişimi veya şahsi güvenliği tehlikede olmak şartıyla ana ve/veya babası belli olmayan bir çocuk olabileceği gibi ana ve/veya babası tarafindan terk edilmiş ya da ana ve/veya babası tarafından ihmal edilmiş bir çocuk da olabilir (SHK m. 3/I (b) bendi) ${ }^{36}$. Bu Kanun'a göre, korunmaya ihtiyacı olan çocuğun bu sebeplerle fuhuş, dilencilik, alkollü içkileri veya uyuşturucu maddeleri kullanma gibi her türlü sosyal tehlikelere ve kötü alışkanlıklara karşı savunmasız bırakılmış ve başıboşluğa sürüklenmiş olması da gerekir.

Türk Medenî Kanunu'nda ise, korunmaya ihtiyacı olan çocuk ifadesi açıkça kullanılmamıştır. Bununla birlikte, TMK m. 347/I'den hareketle, bedensel ve zihinsel gelişimi tehlikede olan veya manen terk edilen çocuğun "korunmaya ihtiyacı olan çocuk" olduğu sonucuna varılabilir.

34 Doğan 149-150.

35 Yakın tarihli bir raporda bu durum ifade edilmiştir (Gündüz, Olgun: Türkiye'de Çocuklara Yönelik Koruyucu ve Önleyici Politikaları Değerlendirme Çalıştayı Raporu 2017, Çocuk Hizmetleri Genel Müdürlüğ̈̈ Yayın No:05, s.16-17). KAY m. 8/VI'da koruyucu ailenin belirlenmesinde öncelik akrabalara veya belirli süredir devam eden ana-baba-çocuk ilişkisinin kurulduğu yakın çevre ailelerden uygun olanlara verilir. Bu kişilerin koruyucu aile olmak istemeleri hâlinde, Komisyon tarafından uygun görülürse yaş ve eğitim şartı aranmaz. Bu koruyucu aile “Akraba ve Yakın Çevre Koruyucu Aile Modeli"dir.

36 2828 sayılı Kanun öncesinde 6972 sayılı Korunmaya Muhtaç Çocuklar Hakkında Kanun yürürlükteydi. Bu Kanuna ilişkin bkz. Zevkliler, Aydın: “Türk Hukukunda Korunmaya Muhtaç Çocuklar", AÜHFD, C.25, Sa.1, 1968, s. 173-236. 


\section{Korunma Kararı}

Türk hukukunda çocuk hakkındaki korunma kararı, ÇKK'ye göre yetkili ve görevli mahkemece alınır (SHK m. 22). Korunmaya ihtiyacı olan çocuğun ana ve babadan alınarak koruyucu aile yanına yerleştirilebilmesi için, hâkim tarafından "çocuğun korunmasına yönelik önlemlerden çocuğun yerleştirilmesine" karar verilmiş olması gerekir (TMK m. 347). Ancak bu hâlde de SHK m. 22'ye göre mahkemeden çocuk hakkında korunma kararı alınmış olmalıdır ${ }^{37}$. Bu karar, ÇKK'de "koruyucu tedbirler" kapsaminda düzenlenir.

Doktrinde "korunma kararı" denilen bu karar, çocuğun ana ve babadan alınarak devletin koruması altına alınması anlamına gelir ${ }^{38}$. Esasen koruma önlemine TMK m. 347'ye dayanarak karar verildiği hâllerde görevli mahkeme, Aile Mahkemelerinin Kuruluş Görev ve Yargılama Usullerine Dair Kanun' ${ }^{39}$ göre aile mahkemeleridir (m. 6/II (b) bendi) ${ }^{40}$. Yargitay da çocuğun suça sürüklenen çocuklardan olmadığ1 buna karşılık bedensel ve zihinsel gelişmesi tehlikede veya manen terk edilmiş olduğu hâllerde, çocuğun ana babadan alınarak bir aile yanına veya kuruma yerleştirilmesine ilişkin karar vermede aile mahkemelerini görevli görmüştür ${ }^{41}$. Burada hukukî korunma talebi ile devletin hukukî ilişkiye müdahalesi istendiğinden ve hâkim re'sen harekete geçebildiğinden bu koruma önlemlerinin alınması çekişmesiz yargı işidir ${ }^{42}$. Kanaatimizce bu karar nihaî bir karar niteliğindedir ${ }^{43}$. Ancak yargılama esnasında hâkim, gecikilmesinde çocuğun menfaatine aykırı

37 Türk Medeni Kanununun Velayet, Vesayet ve Miras Hükümlerinin Uygulanmasına İlişkin Tüzük m. 3/I (10/8/2003 tarih ve 2519 sayılı R.G.).

38 Usta Sayıta, 41; Özdemir Uluç, 74; İnan, Ali Naim: “Çocuk Hukuku Bakımından Korunma Kararı, Koruma ve Emniyet Tedbiri Kavramları", SÜHFD, C.5, Sa.1-2, 1996, s. 2.

39 9.1.2003 tarih ve 4787 sayılı Kanun için bkz. 18.01.2003 tarihli ve 24997 sayılı R.G.

40 Aynı yönde bkz. Grassinger, 147; Usta, Çocuk Hakları, 174; Gençcan, 389-390.

$41 \quad$ Bkz. Yarg. 17. HD'nin 23.10.2014 tarih, E.2014/13906 ve K.2014/14053 ve 6.11.2014 tarih, E.2014/16118 ve K.2014/15323 sayılı kararları ile 20. HD'nin 10.04.2015 tarih, E.2015/1262 ve K.2015/2914, 4.11.2015 tarih, E.2015/12113 ve K.015/10488 ve 14.06.2016 tarih, E.2016/196 ve K.2016/6895 sayılı kararları.

42 Erişir, Evrim: Geçici Hukuki Korumanın Temelleri ve İhtiyatî Tedbir Türleri, İstanbul 2013, s.262; Grassinger, 95; Usta, Çocuk Hakları, 174.

43 Erişir, 265. 
bir tehlikeli durum tespit ederse, çocuğun geçici önlemle koruma altına alınmasına da karar verebilir ${ }^{44}$. Sadece bu hâlde verilen karar, aile hukukuna özgü geçici hukukî koruma önlemi niteliğindedir ${ }^{45}$.

Çocuk Koruma Kanunu'na göre adlî ve idarî merciler, kolluk görevlileri, sağlık ve eğitim kuruluşları, sivil toplum kuruluşları yanında çocuğun kendisi ile ana ve babası, vasisi ${ }^{46}$ ve çocuğun bakımından sorumlu kimseler korunmaya ihtiyacı olan çocuğu AÇSHB'ye bildirmekle yükümlüdür. Bakanlık bunun üzerine gerekli ise çocuk hâkiminden barınma tedbiri kararı ister (m. 6). Savcılık da, bir suç soruşturması esnasında mağdur çocuğun korunma ihtiyacı olduğunu görürse çocuk hâkimliğine başvurur (m. 7).

Sosyal Hizmetler Kanunu'nda da AÇSHB, korunmaya ihtiyacı olan çocukları tespit ve incelemekle görevlendirilmiştir. Mahalli mülki amirler, sağlık kuruluşları ve köy muhtarları ile genel kolluk kuvvetleri ve belediye zabıta memurları bu çocukları Kuruma duyurmakla ve Kurumla işbirliği yapmakla yükümlüdürler (m. 21). Korunmaya ihtiyacı olan çocuk hakkında ÇKK'ye göre barınma tedbirine karar verilmesinde, çocuk mahkemesi veya hâkimi görevlidir (ÇKK m. 7). Çocuk mahkemesi bulunmayan yerlerde, bu mahkeme göreve başlayıncaya kadar korunma ihtiyacı olan çocuklar hakkında tedbir kararları görevli aile veya asliye hukuk mahkemelerince alınır (Geçici m. 1/IV) ${ }^{47}$. Dolayısıyla bir yerde çocuk mahkemesi kurulmamışsa ÇKK'ye göre alınacak tedbir kararlarını da görevli aile mahkemesi veya asliye hukuk mahkemesi verir ve hâkimin verdiği koruyucu ve destekleyici tedbir kararı, aile hukukundaki çekişmesiz yargı işlerindendir (Hukuk Muhakemeleri Kanunu m. 382/II (b) bendi c. 18).

\footnotetext{
$44 \quad$ Erişir, 336.

45 TMK m.346 vd. hükümlerine göre verilen kararların geçici hukuki koruma niteliğinde olduğu yönünde bkz. ve krşz. Tanrıver, Süha: Türk Aile Mahkemeleri, Ankara 2014, s. 44.

46 Vasinin bu yönde talepte bulunması, vesayet makamı sulh mahkemesinin iznine tabidir (TMK m.462/b.13).

47 Bkz. Yarg. 20. HD'nin 29.02.2016 tarih, E.2015/16457 ve K.2016/2421 ve 07/02/2017 tarih, E.2016/14408 ve K.2017/896 sayılı kararları.
} 
Şu hâlde korunmaya ihtiyacı olan çocuklara ilişkin barınma tedbiri kararı vermede, kural olarak, çocuk hâkimi görevlidir. Ancak hakkında derhal korunma tedbiri alınmasında zorunluluk görülen çocuklar, mahkeme tarafından acil korunma kararı alınıncaya kadar, mahalli mülki amirin onayı alınarak bu Kanuna göre kurulmuş kuruluşlarda veya koruyucu aile yanında bakım altına alınabilir (SHK m. 22). Bu hâlde, kolluğun çocuk birimi, çocuğu mümkün olan en kısa sürede AÇSHB'ye teslim eder (ÇKK m. 31/V). Ancak bu hâlde de beş gün içinde çocuk hâkimliğinden acil korunma kararı istenir ve çocuk hâkimi üç gün içinde konu hakkında karar verir. Hâkim çocuk hakkında acil korunma kararı verdiğinde, AÇSHB'nin otuz gün içinde sosyal inceleme yapması ve sosyal inceleme sonucuna göre çocuk hakkında koruyucu ve destekleyici tedbir kararı alınması ya da çocuğun aileye teslimi için çocuk hâkimine başvurması zorunludur (ÇKK m. 9).

Kanaatimizce çocuk hakkında çocuk hâkimince verilen acil korunma kararları ile barınma tedbirleri geçici hukukî koruma niteliğindedir. Zira bu tedbir kararlarına karşı itiraz yolu açıktır (m. 14) ve tedbir kararlarının uygulanması, kararı veren hâkim veya mahkeme tarafından en geç üçer aylık sürelerle incelettirilir (m. 8). Kararların bu özellikleri, bunların nihaî karar olmadığını; çekişmesiz yargı alanında verilmiş geçici hukukî koruma önlemi olduğunu gösterir ${ }^{48}$. Bu hâlde bu kararların kısmî karar olup olmadığı sorusu akla gelmektedir. Kısmî karar uyuşmazlığ geleceğe etkili olarak sona erdiren ve kesin hüküm oluşturan nihaî kararlar olduğundan, geçici hukukî koruma önlemlerinin kısmî karar olduğu kabul edilemez ${ }^{49}$.

\section{KORUYUCU AİLE SÖZLEŞMESINNIN HUKUKÎ NİTELİĞİ}

Koruyucu aile sözleşmesi Aile, Çalışma ve Sosyal Hizmetler İl Müdürlügü ile koruyucu aile arasında imzalanır ve koruyucu ailenin yükümlülüklerini içeren mahalli mülki amir onaylı belgedir (KAY m. 4/I (m) bendi). Sadece hakkında korunma kararı alınmış çocuklara ilişkin

\footnotetext{
48 Benzer yönde bkz. Günay İnan, Esra: Aile Hukukunda Geçici Hukukî Himaye Tedbirleri, Ankara 2018, s. 159.

49 Bahadır, Zeynep: Medenî Usul Hukukunda Kısmî Karar, Ankara 2018, s. 41-43.
} 
olarak koruyucu aile sözleşmesi yapılabilir. Bu sözleşmenin tarafları arasında çocuk ve çocuğun ana babası yer almaz.

Uygulamada koruyucu aile yanında bulunulan süre evlat edinme için deneme süresi olarak değerlendirilmiştir ${ }^{50}$. Oysa koruyucu aile sözleşmesi ne "evlat edinmedir" ne de evlat edinme için bir basamaktır ${ }^{51}$. Zira evlat edinmede bir çocuk aile yanına yerleştirildiğinde aile ile kurum arasında "geçici bakım sözleşmesi" imzalanır. Bu sözleşme bir yıl geçerlidir ve bu süre boyunca aile ile çocuk sosyal hizmet uzmanlarınca izlenir. Bu izlem esnasında herhangi bir risk tespit edilmezse, aile evlat edinmek üzere dava açma hakkı kazanır ${ }^{52}$. Ayrıca koruyucu aile sözleşmesinin temelinde, evlat edinmeden farklı olarak, salt çocuğun üstün menfaati yer alır. Koruyucu aileden beklenen, bakımını ve yetiştirilmesini üstlendiği çocuğu, kendi çocuğu olmadığını unutmadan, kendi çocuğu gibi koruması ve yetiştirmesidir53. Özellikle hastalık, hükümlülük, işsizlik veya ana ve/veya babanın kaybı gibi durumlarda ana ve/veya babanın geçici bir süre çocuğa bakamadığı ancak bir süre sonra çocuğu yanına alabileceği durumlarda korunma kararlı çocuğun koruyucu aile yanına yerleştirilmesi uygundur ${ }^{54}$. Türkiye'de ise, çoğunlukla koruyucu ailelerin yanlarına yerleştirilen çocuğu gelecekte evlat edinmek istedikleri ve bu amaçla korunmaya ihtiyacı olan çocuğun koruyucu ailesi olmak istedikleri tespit edilmiştir ${ }^{55}$. Oysa koruyucu aile bakımı,

$50 \quad$ Usta Sayıta, 105.

51 Doğan, 150.

52 Karataş, 67.

53 Erol/Şimşek, 149. Ancak bilimsel araştırmalarda koruyucu aileler, yanlarındaki çocukların ana ve babaları tarafından geri alınacağı korkusu ve kaygısı yaşadıklarını belirtmişlerdir (Tezel, Zeynep/Demirel, Barış/Kaya, Zühal Şahin: "Ailelerin Koruyucu Aile Olmaya Karar Vermelerinde Etkili Olan Etmenler ile Koruyucu Aile Olmanın Anlam ve Önemi", Sosyal ve Beşerî Bilimler Araştırmaları Dergisi, C.19, Sa.43, 2018, s.32). Oysa koruyucu aile bakımında nihai hedef bu bakımın geçici olması ve sorunlar geçtiğinde çocuğun ana ve babasının yanına dönüşünün sağlanmasıdır.

54 Serdar, 484.

55 Akyüz, 111. Bunda 746 sayılı Türk Kanunu Medenîsi'nin evlat edinmeyi zorlaştıran hükümleri (özellikle evlat edinenlerin 35 yaşını doldurmuş olması şartı) de etkili olmuştur (Karataş, Kasım: “Türkiye'de Çocuk Koruma Sistemi ve Koruyucu Aile Uygulamaları Üzerine Bir Değerlendirme", Koruyucu Aile, Evlat Edinme 
salt korunmaya ihtiyacı olan çocuğun bir aile yanında korunmasını ve bakımını sağlayan, Çocuk Hakları Genel Müdürlüğü'nün denetimi ve gözetimi altında yürütülen alternatif bakım hizmetidir. Bununla, evlat edinmeden farklı olarak, çocuk, koruyucu ailenin velâyeti altına girmediği gibi koruyucu aileyle çocuk arasında hısımlık bağı da kurulmaz ${ }^{56}$.

Doktrinde bir görüş, il müdürlükleri ile koruyucu aile arasında korunmaya ihtiyacı olan çocuk (üçüncü kişi) yararına imzalanan sözleşmeyi, vekâlet unsurları ağır basan sui generis bir aile hukuku sözleşmesi olarak nitelendirmiştir ${ }^{57}$. Bu sözleşme özel hukuk alanında sonuç doğurduğundan, idari bir sözleşme değildir ${ }^{58}$. Zira koruyucu aile, çocuğun bakım ve yetiştirilmesini AÇSHB'nin gözetimi ve denetimi altında yerine getirmekteyse de ne bir kamu hizmeti görür ${ }^{59}$ ne de bir kamu görevlisidir. Sadece AÇSHB, "korunmaya ihtiyacı olan çocuğun bakımı ve yetiştirilmesi” görevini, bu sözleşme ile gerçek kişilere (koruyucu aileye veya kişiye) bırakır. Bu kişiler ise, idarenin bu görevin yerine getirilmesinde başvurduğu "yardımcı kişi" niteliğindedir ${ }^{60}$. Hatta Türk hukukunda koruyucu ailenin uygulama esaslarının, evlat edinmede olduğu gibi, özel hukuk alanında bir tüzükle düzenlenmesi gereği belirtilmiştir ${ }^{61}$.

Doktrinde bir diğer görüşe göre, koruyucu aile vesayet organı değildir. Türk hukukunda vesayet organları vesayet daireleri ile vasiler ve kayyımlardır (TMK m. 396). Buna TMK m. 431/I'den hareketle yasal

Hizmetleri ve Ruh Sağlığı, (Editör: Erol, Neşe), Ankara 2008, s.50). Gerçekten de 4721 sayılı Türk Medenî Kanunu ile evlât edinecek kişinin yaşı 35'ten 30'a ve hatta bazı durumlarda daha da aşağıya çekilmiştir. Ayrıca altsoyu bulunan kişilerin küçükleri evlât edinmesine de izin verilmiştir (Aydos, Oğuz Sadık: “Yeni Medeni Kanuna Göre Evlat Edinme", GÜHFD, C.4, Sa.2, 2000, s.117, 140-141).

Akyüz, 111-112; Yazıcı, 264; Özdemir Uluç, 46-47; Grassinger, 16.

$57 \quad$ Usta Sayita, 77.

58 Özdemir Uluç, 94; Doğan, 164.

59 Doğan, 164.

60 Usta Sayıta, 77.

61 Doğan, 169. 
danışmanlar da eklenmektedir ${ }^{62}$. Koruyucu aile vesayet organının yetki ve görevlerine sahip olmadığından, vesayet organı sayılamaz. Ancak yardımcı vesayet organı olarak nitelendirilebilir. Gerçekten de koruyucu aile ile çocuk arasında ne velâyet ne vesayet ilişkisi kurulur. Koruyucu aile, sadece çocuğun şahsını korur ve amacı ile bağlantılı olarak çocuğun bakım, gözetim ve yetiştirilmesi konuları ile yetkilidir. Diğer bir deyişle çocuğun menfaati gerektirdiği ölçüde, velâyet hakkından doğan birtakım görevleri, devletin denetim ve gözetimi altında yerine getirir ${ }^{63}$.

Esasen yukarıdaki iki görüş birbirini tamamlar. Nitekim ilk yaklaşıma göre koruyucu aile korunmaya ihtiyacı olan çocuklar bakımından AÇSHB'nin yardımcısıdır ve bu kurum, korunmaya ihtiyacı olan çocuğun ana ve babasının velâyet hakkı kaldırıldığında kanuni vasi, kaldırılmadığı hâllerde ise kanuni kayyım olarak kabul edilmelidir ${ }^{64}$. Dolayısıyla iki görüşte de koruyucu aile vesayet organı yardımcısı olarak değerlendirilmiştir.

Kanaatimizce koruyucu aile, sadece korunmaya ihtiyacı olan çocuğun ana ve babasının her ikisinin de velâyet hakkının kaldırıldığı hâllerde bir vesayet organı olan vasinin yardımcısı olarak görülebilir. Zira koruyucu aile yanına yerleştirilen çocuğun ana ve babasının velâyet hakkı kural olarak devam eder. Sadece mahkeme tarafından TMK m 348'e dayanarak çocuğun ana ve babasının her ikisinin de velâyet hakkı kaldırılmışsa, çocuğa vasi atanır (TMK m. 349). KAY'da korunmaya ihtiyacı olan çocuğun vasisinin aynı zamanda koruyucu ailesi olamayacağı hususu açıkça düzenlendiğinden (m. 8/VIII), koruyucu ailenin çocuğun vasisi olması da mümkün değildir. Dolayısıyla sadece

62 Akıntürk/Ateş, 473-475; Dural/Öğüz/Gümüş, prg.1935. Mehaz İsviçre Medeni Kanunu'nda 1.01.2013'te yürürlüğe giren değişiklikle vesayet hükümlerini düzenleyen üçüncü kısımda köklü değişiklik yapılmıştır. Bununla yetişkinlerin korunmasında vesayet yerine yeknesak şekilde kayyımlık düzenlenmiştir. Ayrıca kanuni danışmanlık Kanun'dan tamamen çıkarılmış ve çocukları koruma makamı tarafından velâyet altında bulunmayan her çocuğa vasi atanacağı düzenlenmiştir (Akçaal Mehmet: “İsviçre Medenî Kanunu'na Göre Kayyımlık Türleri”, DEÜHFD, C.20, Sa.2, 2018, s.65-66, dn.5).

63 Serdar, 474-475.

64 Yazar, bu değerlendirmeyi Sosyal Hizmetler ve Çocuk Esirgeme Kurumu bakımından yapmaktadır (Usta Sayıta, 66-68). Yazarın değerlendirmeleri güncel mevzuata uyarlanmıştır. 
bu hâlde koruyucu ailenin korunmaya ihtiyacı olan çocuğa atanan vasinin ve vesayet dairelerinin yardımcısı, diğer bir deyişle vesayet organı yardımcısı olarak kabulü mümkündür. Bununla birlikte korunmaya ihtiyacı olan çocuğun ana ve babasının her ikisinin velâyet hakkının kaldırılmadığı durumlarda koruyucu ailenin vesayet organı yardımcısı olarak kabulü mümkün değildir. Zira Türk hukukuna göre AÇSHB ne kanuni kayyım ne de kanuni vasi olarak kabul edilebilir. Bu hâlde koruyucu ailenin vekâlet unsurları ağır basan sui generis bir aile hukuku sözleşmesi olan koruyucu aile sözleşmesi ile korunmaya ihtiyacı olan çocuğa karşı velâyetten doğan bazı yükümlülükleri karşılıksız olarak yerine getirmekle yükümlü olan vekil benzeri bir yükümlü sayılması gerekir. Zira aşağıda ${ }^{65}$ açıllandığı üzere koruyucu aile sözleşmesinde koruyucu aileye talebi hâlinde devlet tarafından ödenmesi gereken aylık bakım ödemesi "ücret" niteliğinde değildir. Dolayısıyla koruyucu aile sözleşmesi hukuken ivazlı (karşılıklı) bir sözleşme olarak değerlendirilemez.

Bunun yanında korunmaya ihtiyacı olan çocuk bu sözleşmenin tarafı değildir. Ancak bu sözleşmede alacaklı olan AÇSHB, koruyucu ailenin bu sözleşmeden doğan asli edim yükümlülüğünü sözleşme ilişkisinin dışında kalan bir üçüncü kişiye (çocuğa) ifasını şart koşmaktadır. Üçüncü kişi, sözleşmenin kurulmasına katılmayanları, sözleşmenin tarafları dışındaki kişileri ifade eder ${ }^{66}$. Bu sebeple koruyucu aile sözleşmesinin TBK m. 129 anlamında üçüncü kişi yararına sözleşme olduğu kabul edilmelidir. Nitekim koruyucu aile sözleşmesinde de, üçüncü şahıs yararına sözleşmede olduğu gibi ${ }^{67}$, borçlu konumundaki koruyucu aile alacaklı konumundaki AÇSHB’ye karşı sözleşmeden doğan asli edimi bir üçüncü kişiye (korunmaya ihtiyacı olan çocuğa) ifa edeceğini taahhüt eder. Koruyucu aile sözleşmesinin amacı çocuğun (üçüncü şahsın) karşılıksız bir kazandırma elde etmesine yöneliktir.

65 Bkz. V, A, 1.

66 Akyol, Şener: Tam Üçüncü Şahıs Yararına Sözleşme, İstanbul 2008, s.11; Eren, Fikret: Borçlar Hukuku Genel Hükümler, 17. Baskı, Ankara 2014, s.1141; Hatemi, Gökyayla: Borçlar Hukuku Genel Bölüm, İstanbul 2011, s.283; Erdoğan, İhsan: Borçlar Hukuku Genel Hükümler, 4. Baskı, s.285. 
Kanaatimizce bu sözleşmede vaad edilen edim salt üçüncü kişinin yararınadır ve sözleşmenin amacı üçüncü kişiye doğrudan alacak hakkını ileri sürme imkânı tanımaktadır68. Ayrıca bu sözleşmenin ölünceye kadar bakma sözleşmesinin üçüncü kişi lehine yapıldığı hâllere ${ }^{69}$ benzediği de açıktır. Dolayısıyla koruyucu aile sözleşmesinde her hâlde üçüncü kişinin doğrudan doğruya alacak hakkı olduğu kabul edilmeli; dolayısıyla sözleşmenin tam üçüncü kişi yararına sözleşme olduğu sonucuna varılmalıdır. Elbette üçüncü kişi yararına sözleşmenin bağımsız bir sözleşme tipi olmadığ $1^{70}$ da unutulmamalıdır.

Koruyucu aile sözleşmesinin hukukî niteliği belirlendikten sonra aşağıda bu sözleşmeden koruyucu aile bakımından doğan hak ve yükümlülükler incelenmektedir. Bunların incelenmesi koruyucu aileyle yanına yerleştirilen çocuk arasındaki hukukî ilişkinin değerlendirilmesi bakımından gereklidir.

\section{KORUYUCU AİLENIN KORUYUCU AİLE} SÖZLEŞMESİNDEN DOĞAN HAK VE YÜKÜMLÜLÜKLERİ A. KORUYUCU AİLENİN KORUYUCU AİLE
SÖZLEŞMESINDEN DOĞAN HAKLARI

\section{1. Çocuk İçin Aylık Bakım Ödemesi Talep Hakkı}

Koruyucu aileye yanına yerleştirilen çocuğun bakımı ve yetiştirilmesine karşılık olarak ödeme yapılabileceği gibi koruyucu aile bu işi gönüllü olarak da üstlenebilir. Koruyucu ailelere talepleri hâlinde ödenecek bakım ödemesi belirlenirken çocukların bakım, eğitim, kurs, okul, yemek ve taşıma servisi, harçlık ve benzeri ihtiyaçları esas alınır (SHK m. 23/I c. 2, II).

Koruyucu Aile Yönetmeliği'nde ise, korunmaya ihtiyacı olan çocukların bakım, eğitim ve yetiştirilmelerine ilişkin harcamalara ve çocukların kişisel gelişimleri için gerekli harçlıklarına karşılık olmak üzere talepte bulunan koruyucu ailelere yapılacak ödemeler "aylık bakım ödemesi" olarak ifade edilmiştir (m. 4/I b. 2). Ayrıca koruyucu ailenin

68 Eren, 1146; Hatemi/Gökyayla, 287.

69 Ölünceye kadar bakma sözleşmesinin üçüncü kişi yararına yapıldığı hâllerde aynı görüşte Akyol, 37; Eren, 1147.

70 Hatemi/Gökyayla, 285. 
düzenli bir gelire sahip olması (m. 8/I (ç) bendi) ve koruyucu aile başvurusu kabul edilenlerin iş ve ekonomik koşullarının incelenmesi gerekir (m. 9/I).

Talebi hâlinde koruyucu aileye yapılacak ödeme, kanaatimizce "ücret" niteliğinde değildir"1. Zira koruyucu ailenin korunmaya ihtiyacı olan çocuğu topluma yararlı olmak üzere koruyup yetiştirmesi ücret karşılığında yapılamayacak bir şeref hizmeti niteliğindedir. Gerçekten de koruyucu aile olmada asıl amaç, ana babasından alınan çocuğun aile benzeri ortamda korunmasını ve topluma yararlı bir kişi olarak yetişmesini sağlamaktır. Nitekim KAY da "aylık bakım ödemesinin" koruyucu ailenin gördüğü iş görme ediminin karşılığ1 olmadığını, sadece çocuğun bakım, eğitim ve diğer masraflarına karşılık ödendiği vurgular. Dolayısıyla AÇSHB koruma kararlı çocuklar için yaptığı ödemelerle ilgili olarak nafaka ile yükümlü olanlara dava açmak hakkına sahiptir (SHK m. 30). Bu kişiler öncelikle çocuğun ana babasıdır. Zira çocuğun bakımı, eğitimi ve korunması için gerekli giderleri karşılamak, kural olarak, velâyete sahip olup olmadıklarına bakılmaksızın, ana ve babanın yükümlülüğüdür (TMK m. 327/I, 350/I). Ancak ana babanın buna yetecek malvarlığının bulunmaması hâlinde hâkimin izniyle çocuk mallarından onun bakım ve eğitimine yetecek belli bir miktar sarf edilebilir (TMK m. 327/II). Ana ve baba ile çocuğun ödeme gücü yoksa çocuğun korunmasına yönelik önlemlerin gerektirdiği giderler ile bakım ve eğitim giderleri Devletçe karşılanır (TMK m. 347/III ve 350/II).

\section{Korunmaya İhtiyacı Olan Çocukla Kişisel İlişki Kurma Hakkı}

Koruyucu ailenin yanına yerleştirilen çocuğun ana babası ve diğer yakınlarıyla kişisel ilişkisini sağlama yükümlülüğü aşağıda ${ }^{72}$ değerlendirilmektedir. Bunun yanında özellikle çocuğun koruyucu aile yanına çok küçükken yerleştirildiği ve burada uzun süre kaldığ1 durumlarda, çocuğun koruyucu aile ile ana ve babasına yakın bir duygusal ilişki geliştirmesi mümkündür. Bu hâlde çocuğun koruyucu

71 Doktrinde burada teknik anlamda bir ücret bulunmadığı, bu ödemenin çocuğun bakım ve eğitim masraflarının karşılanması amacıyla yapıldığı değerlendirilmiştir (Usta Sayıta, 86-87). Krşz. Özdemir Uluç, 100-101; Serdar, 500-501).

72 Bkz. V, B, 2. 
aileden alınmasından sonra, çocuk ile arasında sevgi bağı oluşan koruyucu ailelere de çocukla kişisel ilişki kurma hakkı tanınmalıdır. Zira koruyucu aile ilişkisi sona erse de çocuk ve koruyucu aile arasındaki sevgi temelli duygusal bağlar devam edebilir ${ }^{73}$. Çocuk Hakları Komitesi, çocukla kişisel ilişki kurma hakkının, koruyucu aileler için de tanınması gereğini vurgulamıştır ${ }^{74}$.

Kanun'a göre olağanüstü hâller mevcutsa, çocuğun menfaatine uygun düştüğü ölçüde, çocuk ile kişisel ilişki kurulmasını isteme hakkı ana ve baba dışındaki kişilere tanınabilir (TMK m. 325/I). Somut olayda koruyucu ailenin bu hakkının bulunduğu kabul edilebilir. Zira bunda çocuğun da üstün menfaati bulunur. Koruyucu ailenin bu hakkının sınırı, çocukla kişisel ilişki kurulması sebebiyle çocuğun huzurunun tehlikeye girmesi veya diğer önemli sebeplerin bulunmasıdır (TMK m. 325/II). Bununla birlikte üçüncü kişilerin bu hakk1 Kanun'da "olağanüstü hâllerin mevcudiyetine" bağlandığından, mahkemenin buna ilişkin düzenleme yapabilmesi için somut olayda koruyucu ailenin çocuğu görüp sevme ve özlemini giderme imkânının hiç kalmaması hâli de aranmalıdir ${ }^{75}$.

\section{B. KORUYUCU AİLENIN KORUYUCU AİLE SÖZLEŞMESİNDEN DOĞAN YÜKÜMLÜLÜKLERİ}

\section{1. Çocuğun Bakım ve Eğitimini Sağlama Yükümlülüğü}

Türk hukukunda çocuğun bakım ve eğitimi, velâyet hakkı sahibi ana baba için hem hak hem de görevdir ${ }^{76}$. Ana ve baba bu hususta çocuğun menfaatini göz önünde tutmalı; buna karşıllı çocuk da ana babanın sözünü dinlemelidir. Ana ve baba, olgunluğu ölçüsünde çocuğa hayatını düzenleme olanağı tanırlar ve önemli konularda olabildiğince onun düşüncesini dikkate alırlar (TMK m. 339). Ana babanın çocuğun eğitimini sağlama görevinin sınırı ekonomik olanakları ve çocuğun bireysel yetenek ve eğilimleridir. Ana ve babanın bu hakkı ve görevi

73 Serdar, 503.

74 Çocuk Hakları Komitesi, Genel Yorum No. 14 Çocuğun Yüksek Yararı Hakkının Öncelikli Olarak Dikkate Alınması (Madde 3, Paragraf 3) için bkz. Çocuk Hakları Komitesi Genel Yorumları, s. 22.

75 Akıntürk/Ateş, 398.

76 Dural/Öğüz/Gümüş, prg.1700; Hatemi/Kalkan Oğuztürk, 191; Akıntürk/Ateş, 412. 
genel, mesleki ve dini eğitimi kapsar (TMK m. 340/II, m. 341/I). Çocuğun eğitimi ailede başlar. Çocuk okul yaşına geldiğinde okul eğitimini alması sağlanır. Genel eğitim çocuğun ilk ve orta öğrenimini kapsar. Ardından çocuğun mesleki eğitimi gelir. Din ve vicdan özgürlüğü ile çocuğun mutlak nitelikteki kişilik hakkı dikkate alınarak, ana ve baba tarafından, çocuğun dini eğitimi de belirlenir ${ }^{77}$.

Çocuğun koruyucu aile yanına yerleştirildiği durumlarda ise, çocuğun bakımı ve korunması hususunda çocuğun yanına yerleştirildiği koruyucu aile görevlidir. Örneğin koruyucu aile, yanına yerleştirilen çocuğun Sağlık Bakanlığı'nın belirlediği aralıklarda sağlık kontrollerini yaptırır ve çocuk hasta olduğunda tedavi plânını uygular (KAY m. 15/I (a) bendi). Koruyucu aile çocuğu koruma, eğitme ve yetiştirme amacı dışında çalıştıramaz (m. 15/I (b) bendi). Kanaatimizce TMK velâyet hakkı sahibi ana ve babayı çocuğun genel, mesleki ve dini eğitimi hususundaki kararları almakla yetkili kıldığından, velâyet hakkı kaldırılmadığı ve koruyucu aile yanına yerleştirilen çocuğun menfaatine aykırı düşmediği sürece, koruyucu ailenin ana ve babanın çocuğun bakımı ve eğitimi hususunda aldığı kararları uygulamakla görevli olduğu sonucuna varılmalıdır. Bununla birlikte KAY çocuk hakkında korunma kararı alındığı her hâlde ana ve babanın velâyet hakkının da kaldırılmış olduğu varsayımı üzerine kurgulanmıştır. Örneğin koruyucu ailenin çocuğun devam edeceği okul, katılacağı kurs, sünnet gibi hayatını etkileyen ve değiştiren önemli konularda ana ve babasıyla değil; sosyal çalışma görevlisi ile birlikte karar alıp uygulaması gerekir (KAY m. 15/I, e). Yine çocuğun zorunlu eğitimi tamamlandıktan sonra yükseköğrenime devam edip etmeyeceği hususunda da, koruyucu aile sosyal çalışma görevlisi ile birlikte çocuğun görüşünü dikkate alarak karar alır. Oysa çocuğun genel ve mesleki eğitimi konusunda, çocuğun yararına uygun düştüğü ölçüde, velâyet hakkı kaldırılmamış olan ana babanın görüşleri dikkate alınmalıdır ${ }^{78}$. Zira çocuğun yetenek ve becerileri ölçüsünde genel, mesleki ve dini eğitimini belirleme görevi velâyet hakkı sahibi ana ve babanındır. Bununla birlikte çocuğun

\footnotetext{
77 Dural/Ögüü/Gümüş, prg.1700-1705; Hatemi/Kalkan Oğuztürk, 191-192; Akıntürk/Ateş, 412-414.

78 Öztan, 1150; Grassinger, 154.
} 
ihtiyaç, istek ve beklentilerini belirlemede ve çocuğu ilgilendiren kararlarda çocuğun düşüncesini almada çocuğun yanına yerleştirildiği koruyucu aile yetkili ve görevlidir (m. 15/I (d) bendi).

Doktrinde çocuğun koruyucu aile yanına yerleştirilirken koruyucu ailenin çocukla aynı dinden olmasına dikkat edilmesi gereği vurgulanmıştır ${ }^{79}$. Zira koruyucu ailenin yanına yerleştirilen çocuğun dini eğitimini belirleme yetkisi yoktur ${ }^{80}$. Koruyucu aile sadece velâyet hakkı sahibi ana ve babanın verdiği karar doğrultusunda, yanlarına yerleştirilen çocuğun dini eğitim plânını uygular.

Koruyucu ailenin yanlarına yerleştirilen çocuk için aylık bakım ödemesi ve eğitim, kurs, servis, harçlık ile diğer giderleri talep ettiği hâllerde, kendilerine yapılan bu ödemeyi yanlarına yerleştirilen çocuğun bakımı ve eğitimi ile diğer giderleri için harcaması gerekir. Kanaatimizce bakım ödemelerini koruyucu ailenin nasıl harcadığı AÇSHB tarafından denetlenmelidir.

\section{2. Çocuğun Ana ve Babası ve Diğer Yakınları ile Kişisel İlişkisini Sağlama Yükümlülüğü}

Korunmaya ihtiyacı olan çocuğun koruyucu aile yanına yerleştirilmesi geçici olmalıdır. Zira korunma kararı kaldırıldığında çocuğun ana babasının yanına dönmesi amaçlanır. Bu sebeple, koruyucu aile yanındayken de çocukla ana babası ve diğer yakınlarıyla arasındaki ilişkinin devamlılığı sağlanmalıdır. Çocuk Haklarına Dair Sözleşme'ye göre taraf devletler ana ve babasından alınmasına karar verilen çocuğun yüksek yararına aykırı olmadıkça, ana ve babasıyla düzenli kişisel ilişki kurma ve doğrudan teması sürdürme hakkına saygı göstermelidirler (m. 9/III). Çocuk Hakları Komitesi de, koruma kararlı çocuğun ailesiyle iletişiminin bu dönemde de olabildiğince devam ettirilmesinin önemini vurgular. Ayrıca bu hak çocuğun ana ve babası yanında çocuğun sıkı kişisel ilişkisi bulunan diğer kişiler için de söz konudur ${ }^{81}$.

\footnotetext{
79 Özdemir Uluç, 111.

80 Usta Sayita, 84; Grassinger, 36.

81 Çocuk Hakları Komitesi, Genel Yorum No.14 Çocuğun Yüksek Yararı Hakkının Öncelikli Olarak Dikkate Alınması (Madde 3, Paragraf 3) için bkz. Çocuk Hakları Komitesi Genel Yorumları, s.22.
} 
Yukarıda vurgulandığı üzere, Türk hukukunda çocuğun ana ve babasıyla kişisel ve doğrudan ilişki kurma ve sürdürme hakkı Anayasa ile güvence altına alınmıştır (m. 41/III). Bu hakka sadece çocuğun yüksek yararına açıkça aykırı olduğunda ve kanunlarla müdahale edilebilir. Bu hak, Kanun'da ana babanın velâyet hakkından bağımsız olarak soybağının hükümleri arasında düzenlenmiştir (TMK m. 323). Dolayısıyla çocukla arasında soybağı kurulmuş ancak velâyet hakkına sahip olmayan ana ve baba açısından bu hak söz konusu olur ${ }^{82}$. Ancak çocuk ile arasında soybağının anayla evlilik, tanıma ya da ana veya çocuk tarafından açılan babalık davası sonucunda verilen babalık hükmüyle kurulmamış olduğu hâllerde baba bakımından bu hak bulunmaz.

Koruyucu aile yanına yerleştirilen çocuğun ana ve babasının velâyet hakkına sahip olmaması, ana ve babasının hiç evlenmemiş olmalarından kaynaklanabileceği gibi, boşanmış ya da ayrılığına karar verilmiş ya da ana ve babadan birinin velâyet hakkının kaldırılmasından (m. 348) kaynaklanabilir. Dolayısıyla koruyucu aile yanına yerleştirilen çocukla arasında soybağı kurulmuş ana ve babanın çocukla kişisel ilişki kurma hakkı bulunur. Ancak mahkeme tarafından buna yönelik bir düzenleme yapılıncaya kadar, çocuk kendisine bırakılmış koruyucu ailenin rızası dışında ana ve baba bu hakkını kullanamaz (m. 326/III). Ayrıca böyle bir kişisel ilişki sebebiyle çocuğun huzuru tehlikeye düşer veya ana ve baba çocukla ciddi biçimde ilgilenmezler ya da başka önemli sebepler varsa, kişisel ilişki kurma hakkı reddedilebilir veya kendilerinden alınabilir (m. 324/II). Benzer şekilde çocuğun menfaatine aykırı olursa, üçüncü kişilere de tanınabilen çocukla kişisel ilişki kurma hakkı reddedilebilir veya kendilerinden alınabilir (m. 325).

Kanaatimizce koruyucu aile yanındaki çocuğun ana babası ve diğer yakınları ile kişisel ilişki kurma hakkı, her hâlde reddedilememelidir. Ancak hâkim somut olayda çocuğun ana ve babadan alınmasına karar verilmesine sebep olan olaydan bizzat ana ve babanın yahut çocuğun herhangi bir yakınının sorumlu olduğunu belirleyebilir. Bu hâllerde çocukla ana ve baba ya da olaydan sorumlu 
olan yakını arasındaki kişisel ilişki kurma hakkı reddedilmelidir. Zira çocukla kişisel ilişki kurma hakkı, çocuk kendilerinden alınmış olsa dahi ana ve babanın kişilik hakkına dahil değerlerdendir ve çocuğun yanına yerleştirildiği koruyucu aile bu hakkın kullanılmasını sağlamakla yükümlüdür83. Diğer bir deyişle koruyucu aile buna katlanmalıdır. Nitekim çocuğun koruyucu aile birimince uygun görülen şekil ve zamanda ana babası ve diğer yakınlarıyla görüştürülmesi koruyucu ailenin bir yükümlülüğü olarak düzenlenmiştir (KAY m. 15 (c ) bendi).

$\mathrm{Bu}$ hak, çocuğun ziyaret edilmesi ya da çocuğun ana ve babasılyla mektup, telefon ve sair iletişim araçlarıyla görüştürülmesi şeklinde kullandırılabilir ${ }^{84}$. Koruyucu ailenin çocuğa ana babasını unutturacak, onları kötüleyerek onlara karşı soğukluk ve yabancılaşma yaratacak telkinlerde bulunması koruyucu ailenin bu yükümlülüğüne açık aykırılık oluşturur ${ }^{85}$. Ancak korunmaya ihtiyacı olan çocuğun ailesi ve yakınlarıyla kişisel ilişkisi Aile, Çalışma ve Sosyal Politikalar İl Müdürlüğünün bilgisi dâhilinde kurulur (KAY m. 15 (ç) bendi). Çocukla kişisel ilişki kurmanın masraflarına, kişisel ilişki kuran katlanır ${ }^{86}$. Koruyucu ailenin bu kişisel ilişkinin kurulabilmesi için çocuğu hazırlama yükümlülüğü vardır.

Koruyucu aile yanına yerleştirilen çocuğun talebi ve sosyal inceleme ile uygun görülmesi hâlinde, çocuğun yaşantısını etkilemeyecek aralıklar ve sürelerle, tatil günlerinde olmak üzere yıl içerisinde en fazla otuz güne kadar ana ve babasına ya da yakınlarına

83 Bkz. Dural/Öğüz/Gümüş, prg. 1655-1656; Akıntürk/Ateş, 396.

84 Bkz. Dural/Öğüz/Gümüş, prg. 1659.

85 Serdar, 496; Grassinger, 155-156. Koruyucu aile ana babayla duygusal rekabete girmemelidir (Erol/Şimşek, 149). Ancak birlikte koruyucu aileler, çocukla ilişkilerinin en azından psiko-sosyal açıdan gerçek bir aile gibi olmasını arzularlar. Bu sebeple çocuğun ailesiyle ilişkisine olumsuz etki edebilirler. Bu sebeple ailelere koruyucu aile eğitimlerinde bu müessesenin gerçek amacı öğretilmelidir (Karataş, Koruma Sistemi, 53). Ancak koruyucu aile eğitimi almış bir aile bile, yanlarına yerleştirilen çocuğun başkası tarafından evlat edinilmek üzere kendilerinden geri alınması durumunda yakın tarihte idareyi Kamu Denetçiliği Kurumu'na şikâyet etmiştir. Ailenin şikâyet gerekçesi ise, koruyucu ailelerin yanlarına yerleştirilen çocuğu evlat edinmede önceliğinin bulunduğuna inanmalarıdır (Kamu Denetçiliği Kurumu'nun 25.07.2016 tarih, 2016/203 şikâyet numaralı kararı). 
izinli verilmesi de mümkündür. Çocuk bu dönemde koruyucu aileden koruyucu aile birimince alınır ve izin bitiminde aynı yöntemle koruyucu aileye geri verilir. $\mathrm{Bu}$ izin esnasında çocuğun ana ve babası ya da yakınları tarafından ihmal edildiği, istismara uğradığı ya da kötü muamele gördüğü belirlenirse, çocuğun yanına izinli verildiği kişi hakkında yasal işlemler başlatılır ve çocuk bir daha bu kişiye izinli verilemez (KAY m. 17). Çocuğun ana ve babasına izinli verilmesi durumunda çocukta bu izin sonrası gözlenen davranışlar ve psikolojik durum sosyal çalışma görevlisince incelenir ve forma işlenir (KAY m. 16/III (a) bendi). Mahkeme tarafından korunma kararının kaldırılmasına ve çocuğun ana ve babasına dönüp dönmeyeceğine karar verilmesinde bu raporlar göz önünde bulundurulur.

\section{Koruyucu Aile Birimi ve Sosyal Çalışma Görevlisi ile İşbirliği Yapma Yükümlülüğ̈̈}

Koruma altına alınan çocuğun ana ve babasılla koruyucu aile arasındaki ilişki, sosyal çalışma görevlisi tarafından yapılan ziyaretlerle sağlanır. Ayrıca çocuğun sosyal, duygusal ve zihinsel güvenliğinin korunması bakımından da bu ziyaretler önemlidir. Ancak uygulamada bazen koruyucu aileler yanlarına yerleştirilen çocuğu kendi çocuğu gibi gördüğü ve bu çocuğu daha sonra evlat edinmek istedikleri için, sosyal çalışma görevlisi tarafından yapılan ziyaretleri olumlu karşılamazlar ${ }^{87}$.

Koruyucu aile ve çocuk arasındaki ilişkinin koruyucu aile birimi tarafından izlenmesi ${ }^{88}$ ve denetlenmesiyle koruyucu aile bakımından beklenen fayda gerçekleşir. Koruyucu aile sorumlu sosyal çalışma görevlisinin periyodik izlemini ve mesleki yönlendirmesini kabul etmek, sosyal çalışma görevlisi ile tedbir kararlarıyla ilgili uygulama planı doğrultusunda iş birliği yapmakla yükümlüdür (m. 15/I (g) bendi).

Koruyucu aile, salt korunma kararlı çocuğun emeğinden yararlanmak amacıyla da bu görevi üstlenmiş olabilir. Bu hâlde koruyucu aile ilişkisi toplumsal hayatımızda geçmişte var olan

\footnotetext{
87 Serdar, 498.

88 Çocuğun izlenmesine ilişkin esaslar için bkz. KAY m.16.
} 
"besleme $e^{89 " ~ g i b i ~ u y g u l a m a l a r ı n ~ t e k r a r ~ c a n l a n m a s ı n ı n ~ o ̈ n u ̈ n u ̈ ~ a c ̧ a b i l i r . ~}$ Korunmaya ihtiyacı olan çocukların hizmetçi veya bakıcı gibi kullanılması sebebiyle koruyucu aile tarafından sömürülmesi ${ }^{90}$, koruyucu ailenin koruyucu aile birimi tarafından sıklıkla izlenmesi ve denetlenmesi yoluyla önlenebilir ${ }^{91}$.

\section{Yerleşim Yeri Değişikliklerini Bildirme Yükümlülü̆ğü}

Çocuğun koruyucu aile yanına yerleştirilmesinden sonra çocuğun oturma yerini belirleme hakkı, velâyet sahibi ana ve babanın değildir ${ }^{22}$. $\mathrm{Bu}$ hâlde "Diğer hâllerde çocuğun oturma yeri, onun yerleşim yeridir (TMK m. 21/I son cümle)" hükmünden hareketle, koruyucu ailenin yerleşim yerinin çocuğun yerleşim yeri olduğu kabul edilmelidir. Her ne kadar TMK m. 22'ye göre bir bakım kurumuna konulma yerleşim yeri edinme sonucunu doğurmamaktaysa da; koruyucu aile yanına yerleştirme bir bakım kurumuna konulma anlamina gelmez. Nitekim Yargitay da, koruyucu aile sözleşmesi ile koruyucu aile yanına uzun süreli yerleştirilen çocuğun yerleşim yerinin koruyucu ailenin bulunduğu yer olduğunu kabul etmiştir ${ }^{93}$.

Somut olayda korunmaya ihtiyacı olan çocuğun ana babasının her ikisinin de velâyet hakkı kaldırılmışsa, çocuk vesayet altına alınır. Bu hâlde, çocuğun yerleşim yeri bağlı olduğu vesayet makamının bulunduğu yer olur (TMK m. 21/II).

Koruyucu ailenin ve korunmaya ihtiyacı olan çocuğun koruyucu aile birimi tarafından izlenip denetlenebilmesi için, koruyucu ailenin yanına yerleştirilen çocuğu, il müdürlüğünün uygun görüşünü almadan başka bir kişi veya ailenin yanına bırakarak oturma yerini değiştirmemelidir (KAY m. 15/I (h) bendi). Ayrıca koruyucu aile kendi

Besleme müessesesinin koruyucu aileden ayrıldığı noktalar hakkında bkz. Usta Sayıta, 37-39; Akyüz, 111. Türkiye'de koruyucu aileden önce geleneksel olarak varlığını sürdüren besleme-evlatlık pratiklerinin gelişim ve değişimi hakkında bkz. Karatay, 398-404.

90 Özdemir Uluç, 35.

91 Serdar, 499-500.

92 Akyüz, 102; Grassinger, 141, 154.

93 Yarg. 18. HD'nin 16.06.2015 tarih, E. 2014/18139 ve K. 2015/10449 sayılı kararı. 
telefon ve adres değişikliklerini öngörülen süreler içinde İl Müdürlüğüne bildirmekle yükümlüdür (m. 15/I (1) bendi).

\section{KORUYUCU AİLE SÖZLEŞMESİNIN SONA ERMESİ}

Koruyucu aileyle çocuk arasındaki hukukî ilişkinin değerlendirilebilmesi, taraflar arasındaki ilişkinin hangi hâllerde ve nasıl sona erdiğinin açıklanmasını gerektirir. Aşağıda koruyucu aile sözleşmesinin kendiliğinden sona erdiği hâllerle mahkeme tarafından korunma kararının kaldırılması ve sözleşmenin olağanüstü fesih yoluyla sona erdirilmesi incelenmektedir.

\section{A. KENDİLIĞİNDEN SONA ERME}

Koruyucu aile sözleşmesi, tam üçüncü kişi yararına bir sözleşmedir. Sözleşmeden yararlanan çocuğun ölümü koruyucu ailenin bu sözleşmeden doğan borcunun ifasını kendiliğinden sona erdirir ${ }^{94}$. Nitekim koruyucu ailenin bu sözleşmeden doğan borcunun ifası çocuğun ölümüyle imkânsız hâle gelir. Bu durumda dar anlamda borcu sona erdiren hâllerden borçlunun sorumlu olmadığı sonraki imkânsızlık söz konusu olur (TBK m. 136/I) $)^{95}$.

Koruyucu aile sözleşmesi, koruyucu aile bakımından şahsi edim yükümlülüğü doğurur. Koruyucu ailenin bir kişiden oluştuğu hâllerde, koruyucu kişinin ölümü de koruyucu aile sözleşmesinden doğan borcu sonraki kusursuz imkânsızlık sebebiyle sona erdirir ${ }^{96}$. Koruyucu ailenin karı kocadan oluştuğu hâllerde ise, her ikisinin ölümü aynı hukuki sonucu doğurur. Diğer taraftan koruyucu aileden sadece birinin öldüğü hâllerde koruyucu ailenin bu sözleşmeden doğan borcu kendiliğinden sona ermez; ancak bu durum AÇSHB tarafından koruyucu aile sözleşmesini feshetmek için haklı bir sebep oluşturur.

94 Usta Sayıta, 95; Özdemir Uluç, 120.

95 Bkz. Eren, 1299 vd.; Hatemi/Gökyayla, 311 vd.

96 Kişi unsurunun önem kazandığ sürekli borç ilişkilerinde kanun koyucu bazen sözleşme bakımından şahsı önemli olan tarafın ölümüne kendiliğinden sona erme sonucunu bağlamış bazen de olağanüstü fesih imkânı öngörmüştür (Seliçi, Özer: Borçlar Kanununa Göre Sözleşmeden Doğan Sürekli Borç İlişkilerinin Sona Ermesi, İstanbul 1976, s. 81). 
Koruyucu ailenin karı ve kocadan oluştuğu hâllerde koruyucu ailenin fiil ehliyetini kaybetmesi ${ }^{97}$ ve vatandaşlıktan çıkması veya çıkarılması hâllerinde de benzer hukukî sonuca varılmalıdır. Zira bir kişinin koruyucu aile olabilmesi için bu görevin sorumluluğunu üstlenebilecek düzeyde ayırt etme gücüne sahip olması gerekir. Yine koruyucu ailenin Türk vatandaşı olması ve Türkiye'de sürekli ikamet etmesi ile 25-65 yaş aralığında bulunması gerekir (KAY m. 8/I a ve b bentleri). Ancak yaş şartı korunma kararlı çocuğun aile yanına yerleştirildiği tarih itibarıyla gerçekleşmelidir. Dolayısıyla bir çocuğun ailenin yanına yerleştirilmesinden sonra koruyucu ailenin 65 yaşını doldurmuş olması bu ilişkiyi sona erdirmez.

Son olarak bu başlık altında şu hususa da yer verilmelidir. Çocuk hakkında hâkim tarafından verilen korunma kararı, kural olarak, çocuk ergin olana kadar devam eder. Dolayısıyla çocuğun ergin olmasıyla, koruyucu aile sözleşmesi de kendiliğinden sona erer ${ }^{98}$. Bununla birlikte mahkeme, korunma kararlı kişinin rızasını alarak, korunma kararının ergin olduktan sonra da devamına hükmedebilir. Korunma kararı, ortaöğrenime devam edenler bakımından yirmi yaşına kadar, yükseköğrenime devam edenler için ise yirmi beş yaşına kadar uzatılabilir. Öğrenime devam etmeyenler bakımından ise, bu süreçte bu kişilerin bir iş veya meslek sahibi olabilmelerinin sağlanması amacıyla yirmi yaşına kadar uzatılabilir (SHK m. 24).

\section{B. KORUNMA KARARININ HÂKİM TARAFINDAN KALDIRILMASI}

Korunma kararına neden olan şartların ortadan kalkması hâlinde, AÇSHB'nin önerisi üzerine, korunma kararı çocuk ergin olmadan da hâkim tarafından kaldırılabilir (SHK m. 24). Yine çocuğun korunmasına yönelik önlemlerin şartların değişmesi hâlinde yeni duruma uydurulması gerekir. Özellikle ana babanın velâyet hakkının kaldırıldığı hâllerde, hâkim, şartlar değiştiğinde ana ve babanın istemi üzerine veya re'sen velâyeti geri verir (TMK m. 351).

\footnotetext{
97 Sonraki kusursuz imkânsızlık, borçlunun ehliyetini kaybetmesi veya sakatlanmasından kaynaklanabilir (Hatemi/Gökyayla, 313).

98 Usta Sayıta, 95; Özdemir Uluç, 121; Serdar, 504.
} 
Koruyucu Aile Yönetmeliği'nde çocuğun koruyucu aileye yerleştirilme nedenlerinin ortadan kalkması ve korunma kararının kaldırılması durumunda, çocuğun koruyucu aileden geri alınacağı (m. 20/I (e) ve (f) bentleri) düzenlenmiştir.

\section{OLAĞANÜSTÜ FESİH YOLUYLA SONA ERME}

Koruyucu aile sözleşmesi koruyucu ailenin sözleşmeden doğan yükümlülükleri bakımından sürekli borç ilişkisi doğurur. Her sürekli borç ilişkisinde olduğu gibi, bu sözleşme de olağanüstü fesih ile derhal sona erdirilebilir ${ }^{99}$. Şu hâlde sözleşmenin tarafları (hem koruyucu aile hem de AÇSHB), bu sözleşmeyi koruyucu aileden ya da korunmaya ihtiyacı olan çocuktan kaynaklanan haklı (önemli) sebeplerle ileriye etkili olarak derhal feshedebilmelidir.

Koruyucu Aile Yönetmeliği'nde ise, kanaatimizce olağanüstü fesih niteliğinde olan bazı hâller "Çocuğun geri alınması" başlığı altında düzenlenmiştir. Zira KAY bu sözleşmeyi bir özel hukuk sözleşmesi olarak değil, idarenin üstün olduğu bir idari sözleşme niteliğinde görmektedir. Ancak kanaatimizce Türk hukukundaki koruyucu aile sözleşmesi özel hukuk sözleşmesi niteliğinde değerlendirilmelidir. Bu sebeple KAY'da AÇSHB bakımından çocuğun geri alınması başlığı altında düzenlenen hâller, hukuken koruyucu aile sözleşmesinin AÇSHB tarafindan ileriye etkili olarak haklı sebeple sona erdirilmesi (olağanüstü fesih) niteliğindedir. Aynı sebeple koruyucu ailenin de sürekli borç ilişkisi doğuran bu sözleşmeyi özellikle korunmaya ihtiyacı olan çocuktan kaynaklanan haklı sebeplerle olağanüstü fesih yoluyla sona erdirmesi mümkündür.

AÇSHB bakımından sözleşmenin haklı sebeple feshedilebileceği hâlleri, KAY göstermektedir. Koruyucu ailenin bu sözleşmeden doğan yükümlülüklerine açıkça aykırı davranması (m. 20/I (a) bendi) ile çocukla koruyucu aile arasında sağlıklı iletişimin kurulamaması (m. 20/I (b) bendi) böyledir. Yine koruyucu ailenin koruyucu aile birimi tarafından denetlenmesi esnasında çocuğun ana ve babasıyla ilişkisini zedeleyecek tutum ve davranışlarda bulunduğunun (m. 20/I (ç) bendi) ve çocuk için koruyucu aile bakımından beklenen yararın 
gerçekleşmediğinin tespit edilmesi (m. 20/I (d) bendi) de haklı sebeptir. Somut olayda çocuğun koruyucu aile tarafindan ihmal ve istismar edildiği, kötü muameleye maruz bırakıldığı da belirlenmiş olabilir. Bu hâllerde ise, çocuk derhâl koruyucu aileden alınır (m. 20/I (c) bendi) ${ }^{100}$ ve koruyucu ailenin çocuğa yönelik eylemleri suç teşkil etmekteyse ayrıca Cumhuriyet Savcılığına suç duyurusunda bulunulur (m. 23).

Koruyucu aileden geri alınan çocuğun, öncelikle ana ve babası yanına dönmesi hedeflenir. Bu mümkün olmadığında, çocuk, AÇSHB tarafından, akraba veya yakın çevre koruyucu aile bakımı kapsamında yerleştirilir. Bunun yapılamaması hâlinde, çocuk durumuna uygun başka bir koruyucu aile yanına yerleştirilir (m. 21/II, III). Bu da mümkün olmazsa, son çare olarak, çocuk kurum bakımına alınır (m. 21/IV).

Bazen somut olayda korunma kararlı çocuğun gelecekte ana babasının yanına dönme olanağı bulunmaz ve çocuk başlangıçta evlat edinilme şartlarını taşımasa da bir süre sonra bu şartlara sahip hâle gelebilir. Özellikle ana babanın başlangıçta korunma altına alınan çocuğun evlat edinilmesine izin vermediği ancak bir süre sonra bu rızayı verdiği hâller böyledir. Bu durumda ilk aşamada koruyucu aile yanına yerleştirilmiş çocuğun, bir süre sonra evlat edinilmeye uygun olduğu sonucuna varılır. Bu hâlde AÇSHB tarafından koruyucu aile sözleşmesi tek taraflı sona erdirilerek çocuk koruyucu aileden geri alınmakta ve evlat edinilmesi çocuğun üstün menfaatine daha uygun olduğundan çocuk evlat edinmeye uygun olan bir başka ailenin yanına "geçici bakım sözleşmesiyle" verilmektedir. Kanaatimizce bu hâl de korunmaya ihtiyacı olan çocuğun durumundan kaynaklı sebeple sözleşmenin olağanüstü fesih yoluyla sona erdirilmesi niteliğindedir. Böyle hâllerde çocuğun yanına yerleştirildiği koruyucu aile, çocuğun üstün menfaatinin gerektirdiği işlemlerin gerçekleştirilebilmesi için her türlü destekte bulunmakla ve çocuğun koruyucu aileden ayrılık sürecine hazırlanmasında iş birliği yapmakla yükümlüdür. Ancak şikâyet üzerine incelediği bir dosyada Kamu Denetçiliği Kurumu koruyucu aile yanına yerleştirilen çocuğun sadece iki ay sonra şartlarının değiştiği

100 Bu hâlde koruyucu aile statüsü iptal edilir ve bu aile yanına bir daha çocuk yerleştirilemez (m. 22/I (a) bendi ve 22/III). 
gerekçesiyle koruyucu aileden alınıp çocuğu evlat edinmek isteyen bir başka ailenin yanına verilmesini makul görmemiş ve idarenin bu durumda çocuğun yararına hareket etmediğini vurgulamıştır ${ }^{101}$.

\section{KORUYUCU AİLE İLE ÇOCUK ARASINDAKİ HUKUKİ İLIŞKİNIN DEĞERLENDİRILMESİ}

Aşağıda şu sorulara yanıt aranmaktadır: Çocuk koruyucu aile sözleşmesiyle koruyucu ailenin "ev düzenine" dahil olur mu? Bu ilişki Anayasa ve Avrupa İnsan Hakları Sözleşmesi'nde (AİHS) güvence altına alınan "özel hayata ve aile hayatına saygı gösterilmesi hakkı" kapsamında korunabilir mi? Koruyucu aile ile çocuk hukuken birbirinin "yakını" sayılabilir mi?

\section{A. EV DÜZENİ İLIŞKİsi}

Kanun'a göre "aile hâlinde yaşayan birden çok kimsenin oluşturduğu topluluk" ev düzenidir. Ev düzeni kan veya kayın hısımlığı, işçilik, çıraklık veya benzeri sebeplerle ya da koruma ve gözetme ilişkisi içinde ev halkı olarak bir arada yaşayanların hepsini kapsar (TMK m. 367). Bu şekilde yaşama, bir düzeni ve bu düzen içinde bazılarının korunmasını ve zarar doğuran davranışlarından ev başkanının sorumluluğu gerektirir. Bu sebeple TMK m. 368 ve 369'da ev başkanlığıyla bundan doğan sorumluluk hüküm altına alınmıştır ${ }^{102}$.

Koruyucu aileyle yanına yerleştirilen çocuk, koruyucu aile sözleşmesine dayanarak bir arada yaşarlar. Ayrıca çocuk koruyucu ailenin otoritesi altındadır. Bu sebeple koruyucu aile ile yanına yerleştirilen çocuk arasında ev düzeni ilişkisi bulunur. Bu ev düzeninde koruyucu aile yanına yerleştirilen çocuk, "ev halkındandır". Koruyucu aile ise, "ev başkanıdır". Somut olayda koruyucu aile evli kişilerden oluşmaktaysa, koruyucu ana ve baba birlikte ev başkanı olurlar. Koruyucu ailenin evli olması zorunlu olmadığından, tek bir kişi de koruyucu aile olabilir. Bu hâlde koruyucu kişi ev başkanı sıfatı kazanır.

\footnotetext{
101 Kamu Denetçiliği Kurumu'nun 25.07.2016 tarih, 2016/203 şikâyet numaralı kararı.

102 Ünal, Mehmet: Türk Medenî Hukukunda Aile Başkanının Sorumluluğu, Ankara 1979, s.25; Dural/Öğüz/Gümüş, prg. 1813; Hatemi/Kalkan Oğuztürk, 205; Akıntürk/Ateş, 454.
} 
Koruyucu ailenin bu düzenin kurallarını belirlerken varsa çocuklarıyla korunmak üzere yanlarına yerleştirilen çocuk arasındaki adil dengeyi gözetmesi gerekir. Ev halkından olan çocuğun öğrenimi, eğitimi, dinî inançları, meslek ve sanatı için gerekli özgürlükten yararlanmasına olanak sağlanmalıdır. Yine çocuğun evdeki eşyası özenle korunmalı ve güvenlik altında bulundurulmalıdır (TMK m. 368).

Ev başkanı olan koruyucu aile, yanına yerleştirilen çocuğun kendi gözetim ve bakımında kaldığı süreçte başkalarına verdiği zarardan sorumludur ${ }^{103}$. Ancak alışılmış şekilde durum ve koşulların gerektirdiği dikkatle onu gözetim altında bulundurduğunu veya bu dikkat ve özeni gösterseydi dahi zararın meydana gelmesini engelleyemeyeceğini ispat ederse sorumluluktan kurtulur (TMK m. 369/I). Koruyucu ailenin bu sorumluluğu olağan sebep sorumluluğu niteliğindedir. Sorumluluk için ev başkanının ve çocuğun kusuru aranmaz Sorumluluk ev başkanının "gerekli özeni göstermemesine"dayanir ${ }^{104}$.

\section{B. KORUYUCU AİLE İLIŞKISIININ “ÖZEL HAYATA VE AİLE HAYATINA SAYGI GÖSTERILLMESI HAKKI" BAĞLAMINDA KORUNMASI}

"Özel hayata ve aile hayatına saygı gösterilmesi hakkı" AİHS m. 8'de koruma altına alınmıştır. Avrupa İnsan Hakları Mahkemesi "aile" ve "aile hayatı" kavramını sözleşme taraflarının iç hukuklarından bağımsız şekilde yorumlar ${ }^{105}$. Gerçekten de AİHM, bireyler arasında aile benzeri yakın kişisel ilişkinin fiilen bulunduğu durumları aile hayatı kapsamında görmektedir. Bunu değerlendirirken salt kişiler arasındaki hukukî bağları değil; sosyal, duygusal ve biyolojik bağları göz önünde bulundurur ${ }^{106}$.

AİHM kararlarında çocuğun esasen ana ve babası yanında büyümesi gerektiği; ancak ailenin bu bakımı sağlayamadığı hâllerde

\footnotetext{
103 Usta Sayıta, 92-93.

104 Dural/Öğüz/Gümüş, prg. 1852; Akıntürk/Ateş, 456-457.

105 Arslan Öncü, Gülay: Özel Yaşama ve Aile Yaşamına Saygı Hakkı, Anayasa Mahkemesine Bireysel Başvuru El Kitapları Serisi - 8, Ocak 2019, s.97.

106 Arslan Öncü, 97; Kanadoğlu, Korkut: "Evlilik ve Ailenin Anayasal Korunması", Anayasa Mahkemesinin Medeni Hukuka İlişkin Kararlarının Değerlendirilmesi Sempozyumu, İstanbul 2013, s.100.
} 
koruyucu aile gibi alternatif bakıma alınabileceği belirtilir. Koruyucu aile, korunmaya ihtiyacı olan çocuklar bakımından geçici çocuk koruma önlemidir. Bu sebeple koruyucu aile yanındayken çocuğun ana ve babasıyla kişisel ilişki kurma hakkı güvence altına alınmalı ve mümkün olduğunca çocuğun ana ve babasının yanına geri dönüşü sağlanmaya çalışılmalıdır. Bu ilkeler, AİHS m. 8/I'de güvence altına alınan "aile hayatına saygı gösterilmesi hakkı"nın gereğidir ${ }^{107}$.

Bununla birlikte her ne kadar aslolan koruyucu aile ilişkisinin geçici olması olsa da, bazı hâllerde koruyucu aile yanına yerleştirilen çocuk çok küçük yaşlardan itibaren koruyucu aileyle uzun süreli aile yaşantısı içinde bulunabilir. Bu durumda koruyucu aileyle çocuk arasındaki sosyal ve duygusal bağ, koruyucu aile ilişkisinin de AİHS m. 8/I'deki "aile hayatına sayg gösterilmesi hakkı" kapsamında korunmasını gerektirir. Nitekim AİHM bir kararında koruyucu aileyle çocuk arasında aile yaşamı bulunup bulunmadığının, çocuğun ana ve babasıyla aile ilişkisinin mevcut olup olmadığı ve çocuğun ne zamandır koruyucu aile yanında kaldığına bakılarak belirleneceğini ifade etmiştir ${ }^{108}$.

Anayasa'da da herkesin özel hayata ve aile hayatına sayg1 gösterilmesini isteme hakkına sahip olduğu belirtilerek, aile hayatının gizliliğine dokunulamayacağı güvence altına alınmıştır (m. 20/I). Aile kavramı tanımlanmamış olmasına rağmen, aile sosyal bir hak olarak devlet korumasına alınmıştır (m. 41) ${ }^{109}$ Anayasa Mahkemesi'ne bireysel bir başvuruda, koruyucu aile statüsünün feshine ilişkin kararın iptal edilmesini konu alan davanın sürüncemede bırakılması sebebiyle aile hayatına saygı gösterilmesi hakkının ihlal edildiği iddia edilmiştir. Anayasa Mahkemesi de, uzun süre koruyucu ailenin himayesi altında yaşamış çocukların koruyucu ailesini ana ve babaları olarak tanımlamaları ve koruyucu aileyle birlikte yaşama iradelerini beyan

107 Çocuk Haklarıyla İlgili Avrupa Hukuku El Kitabı, 88, 91; Arslan Öncü, 120.

108 Bkz. Kilkelly, Ursula: Özel Hayata ve Aile Hayatına Sayg1 Gösterilmesi Hakkı, Avrupa İnsan Hakları Sözleşmesi'nin 8. Maddesi'nin uygulanmasına ilişkin kılavuz, Ankara 2003, s.15. 10.07.1978 tarih, 8257/78 başvuru numaralı X-İsviçre kararında koruyucu aile ve baktıkları çocuklar arasındaki ilişkinin özel yaşam kapsamına girdiği için AİHS m. 8'e göre korunması gereği vurgulanmıştır (Kilkelly, 9).

109 Kanadoğlu, 93-94. 
etmeleri durumunda koruyucu aile ve yanlarına yerleştirilen çocuklar arasında aile hayatı bulunduğu sonucuna varmıştır. Bu sebeple bu çocukların koruyucu aileden ayrılmasını doğuracak işlemlerin yargısal denetimi hızlı yapılmalıdır. Bu durum, çocuğun üstün yararının da gereğidir. Bu yargılamanın hızlı yapılmaması sebebiyle, devletin aile hayatına saygı gösterilmesi hakkından doğan pozitif yükümlülüklerine aykırı davrandığı ve aile hayatına saygı hakkının usul boyutunun ihlâl edildiği sonucuna varılmıştır ${ }^{110}$.

Şu hâlde koruyucu aileyle çocuk arasındaki ilişkinin geçici olması gerekir. Zira şartlar elverişli hâle geldiğinde çocuğun ana babası yanına döndürülmesi amaçlanır. Kanaatimizce de koruyucu aile ve çocuk arasındaki ilişki kural olarak "aile hayatına saygı gösterilmesi hakkı" kapsamında değil; "özel hayata saygı gösterilmesi hakkı" kapsamında korunur. Sadece koruyucu aileyle çocuk arasındaki ilişkinin uzun süreli olduğu ve özellikle çocuğun ana ve babasıyla kişisel ilişkisinin bulunmaması sebebiyle koruyucu aileyi ana ve babanın yerine koymuş olduğu hâllerde bu ilişki "aile hayatına saygı gösterilmesi hakkı" kapsamında korunabilir. Esasen burada çocukla koruyucu aile arasında hukukî veya biyolojik ana ve baba ilişkisinin bulunup bulunmadığına bakılmamakta; sadece aralarında sağlam bir sosyal aile ilişkisinin bulunup bulunmadığ 1 tespit edilmektedir ${ }^{111}$.

\section{KORUYUCU AİLE İLE YANINA YERLEŞTİIILEN ÇOCUĞUN HUKUKÎ ANLAMDA “YAKIN" SAYILMASI}

Koruyucu aileyle yanına yerleştirilen çocuk arasında ne soybağı ne de hısımlık ilişkisi kurulur. Sadece somut olayda bu kişiler arasında yukarıda açıklandığı gibi bir sosyal aile ilişkisi bulunduğu istisnâ̂ hâllerde, bu kişilerin hukukî anlamda birbirlerinin "yakını" da sayılması gerekir. Şu hâlde Türk medenî ve yargılama hukukunda "yakın"

\footnotetext{
110 Anayasa Mahkemesi'nin 27.03.2019 tarih ve 2015/7216 başvuru numaralı kararı (16.04.2019 tarih ve 30747 sayılı R.G.).

111 Bu durum doktrinde bölünmüş anneliğin bir alt türü olarak değerlendirilen "sosyal anneliğe" benzer. Nasıl "sosyal anne", çocukla arasında sağlam bir sosyal aile ilişkisi bulunan ve hukukî veya biyolojik anne sıfatını taşıyıp taşımadığından bağımsız olarak çocuk için sorumluluk üstlenen kadın ise (Keskin, A. Dilşad: "Bölünmüş Annelik ve Ana Yönünden Soybağının Reddi”, ÇÜHFD, C.5, Sa.1-2, 2020, s.1991), kanaatimizce koruyucu aile de bazen "sosyal aile“olarak değerlendirilmektedir.
} 
sayılmaya bağlanan hukukî sonuçların koruyucu aile ve çocuk bakımından söz konusu olup olmadığı ayrı ayrı değerlendirilmelidir.

Koruyucu aileyle yanına yerleştirilen çocuktan biri diğerinin hayatı, sağlı̆̆ı veya namus ve onuruna yönelik pek yakın ve ağır bir tehlike ile korkutularak evlenmeye razı edilmişse, korkunun etkisinin ortadan kalktığı tarihten başlayarak altı ay ve her hâlde evlenmeden itibaren beş yıl içinde bu evlenmenin iptalini dava edebilir (TMK m. 151152). Yine mirasçılardan birinin mirasbırakanın yakınlarından birine karşı ağır bir suç işlemiş olması hâlinde, mirasbırakan, ölüme bağlı bir tasarrufla saklı paylı mirasçısını mirasçılıktan çıkarabilir (TMK m. 510). Koruyucu aile ve yanına yerleştirilen çocuk bu hükümler anlamında birbirlerinin "yakını" sayılmalıdır.

Koruyucu aile veya yanına yerleştirilen çocuktan birinin bir haksız fiil sonucu ölmesi hâlinde, ölenin desteğinden yoksun kalan kişilerin haksız fiil failine karşı TBK m. 55'teki şartlar gerçekleştiği takdirde, destekten yoksun kalma tazminatı talebiyle dava açması mümkündür. Koruyucu aile ilişkisinde bu talebi koruyucu aile yanına yerleştirilen çocuk ileri sürebilir. Zira tazminat isteyen çocuğa fiilen, sürekli ve düzenli bir şekilde bakan veya ona ileride bakması kuvvetle muhtemelen olan kişiye destek denir ${ }^{112}$. Koruyucu aile korunmaya ihtiyacı olan çocuk bakımından "destek" olarak kabul edilebilir. Ancak kanaatimizce koruyucu ailenin böyle bir talebi ileri sürmesi mümkün olmamalıdır. Zira koruyucu aile ve yanına yerleştirilen çocuk arasındaki ilişki, kural olarak, çocuğun ergin olmasıyla kendiliğinden sona erer. Koruyucu aile yanına yerleştirilen çocuğun, ergin olmasından sonra koruyucu aileye yardım ve bakım yükümlülüğü bulunmaz. Bu çocuğun koruyucu aileye "farazi destek" olacağı da düşünülemez. Ancak koruyucu aile veya çocuğun bir haksız fiil sonucu ölmesi hâlinde, sağ kalanın ölüme sebep olan kişiden manevî tazminat isteminde bulunması mümkündür (TMK m. 56/II). Nitekim burada ölene mirasçı olmadığ1 
hâlde ölenle yakınlık ilişkisi bulunanlar manevi tazminat talep edebilmektedirler ${ }^{113}$.

Yine koruyucu aileyle yanına yerleştirilen çocuktan biri, diğerinin davalı ya da davacı olduğu bir hukuk davasında ya da sanık olduğu bir ceza davasında tanıklıktan çekinebilir (HMK m. 248/I (e ) bendi; Ceza Muhakemesi Kanunu m. 48). Benzer şekilde, koruyucu aile, yanına yerleştirilen çocuk ile ilgili bir davada hâkimlikten ve hakemlikten çekinebilir. Çocuk da bu sebeple hâkimi ya da hakemi reddedebilir (Bkz. HMK m. 34/I (a), 36, 417).

\section{SONUÇ}

Bilimsel araştırmalar çocuğun bakımında aile ortamının en uygun yer olduğunu göstermektedir. Bu sebeple, hâkimin olabildiğince çocuğun ana ve babası yanında korunmasına öncelik vermesi gerekir. Ancak çocuğun üstün yararı ana ve babasından alınmasını gerektirdiğinde ve çocuğun küçük yaşlarda olup aile temelli alternatif bakımın çocuğu topluma kazandırmak için gerekli olduğu hâllerde çocuk koruyucu aile yanına yerleştirilmelidir. Türkiye'de son zamanlarda bu gelişmeler doğrultusunda korunma kararlı çocukların koruyucu aile yanına yerleştirilmesi teşvik edilmektedir.

Türkiye'de koruyucu aile yanındaki çocuk sayısındaki artışın koruyucu aileyle ilgili hukukî uyuşmazlıkları hem nicelik hem de nitelik bakımından çeşitlendirmesi mümkündür. Türk hukukunda koruyucu aile bu görevi karşılığında devletten çocuğun bakımı ve yetiştirilmesinde kullanılmak üzere aylık bakım ödemesi talep edebileceği gibi bu görevi hiçbir ödeme talep etmeden de gerçekleştirebilir. Kanaatimizce aylık bakım ödemesi, hukuken "ücret" niteliğinde olmadığından, koruyucu aile sözleşmesi her hâlde ivazsızdır. Koruyucu aile, korunmaya ihtiyacı olan çocuk yararına yapılan bu sözleşme ile karşılıksız olarak çocuğu bakıp büyütme ve korumaya

113 Eren, 798; Erdoğan, 144. Ancak doktrinde TBK m. 56/II'deki "yakın" teriminin dar yorumlanması gerektiği ve buna nişanlı, fiilî eş ve mirasçıları dahil etmenin uygun düşeceği belirtilmiştir (Hatemi/Gökyayla, 155). Kanaatimizce koruyucu aile ile korunmaya ihtiyacı olan çocuk arasında özellikle aile benzeri duygusal ve sosyal ilişkinin kurulduğu istisnaî hâllerde bu kişilerin birbirinin TBK m. 56/II anlamında yakını sayılması gerekir. 
ilişkin bir yükümlülük altına girer. Koruyucu aile, sözleşme boyunca çocuk ile ana babası ve diğer yakınları arasındaki kişisel ilişki kurma hakkına saygı göstermelidir. Zira koruyucu aile bakımında çocuğun sorunlar geçtiğinde ana ve babasının yanına dönüşünün sağlanması amaçlanır. Koruyucu aile yanına yerleştirilen çocuk hakkında, kural olarak, mahkeme tarafından korunma kararı alınmış olmalıdır. Korunma kararının Türk Medenî Kanunu'na göre alındı̆̆ı hâllerde aile mahkemeleri görevlidir. Korunma kararı çekişmesiz yargı işi niteliğindedir. Kanaatimizce bu karar "nihâ̂ bir karardır". Sadece gecikilmesinde çocuğun menfaatine aykırı bir durum varsa, hâkim, çocuk hakkında "geçici hukukî korumaya" da karar verebilir. Çocuk hakkında Çocuk Koruma Kanunu'na göre çocuk hâkimi tarafından verilen acil korunma kararları ile barınma tedbiri ise "geçici hukukî koruma" niteliğindedir.

Koruyucu aile sözleşmesi ne "evlat edinme" ne de evlat edinme için gerekli olan "geçici bakım süresidir". Kanaatimizce özel hukuk sözleşmesi niteliğinde olan bu sözleşme, çocuk yararına imzalandığından tam üçüncü kişi yararına sözleşmedir. Korunmaya ihtiyacı olan çocuğun ana ve babasının her ikisinin de velayet hakkının kaldırıldığı hâllerde koruyucu ailenin çocuğa atanan vasinin yardımcısı olarak kabulü mümkündür. Dolayısıyla koruyucu aile sadece bu hâlde vesayet organı yardımcısı olabilir. Diğer hâllerde ise, koruyucu aile velâyet hakkı kapsamında bulunan bazı görevleri idarenin denetimi ve gözetimi altında çocuğa karşı yerine getirmekle yükümlüdür. Bu sözleşmenin vekâlet unsurları ağır basan sui generis bir aile hukuku sözleşmesi olarak nitelendirilmesi uygundur.

Koruyucu aile sözleşmesi her hâlde ivazsız olup, bir şeref hizmetinin yerine getirilmesi niteliğindedir. Koruyucu ailenin bu sözleşmeden doğan bazı hakları bulunmaktadır. Bunlar, yanına yerleştirilen çocuğun bakım ve eğitiminin sağlanmasına ilişkin kendisine ödenebilecek aylık bakım ödemesini talep hakkı ile koruyucu ailenin bu ilişkinin sona ermesinden sonra çocukla kişisel ilişki kurma hakkıdır.

Koruyucu ailenin bu sözleşmeden doğan çeşitli borçları vardır. Bunlardan en önemlisi, yanlarına yerleştirilen çocuğun bakımı, 
korunması ve eğitimini sağlamaktır. Bir diğer yükümlülüğü, koruyucu aile biriminin denetim ve gözetiminde çocukla ana babası ve diğer yakınları arasındaki kişisel ilişkinin kurulmasını sağlamaktır. Ayrıca bu süreçte koruyucu aile birimi ve sorumlu sosyal çalışma görevlisiyle işbirliği yapmalı ve kendi yerleşim yeri değişikliklerini koruyucu aile birimine bildirmelidir.

Kanaatimizce bu sözleşme özel hukuk sözleşmesi niteliğinde olduğundan, sözleşmeden doğan asli edim yükümlülüğü çocuğun ölümü ve ergin olması gibi durumlarda kendiliğinden sona erer. Yine sürekli borç ilişkisi niteliğinde olduğundan bu sözleşmenin koruyucu aileden veya korunmaya ihtiyacı olan çocuktan kaynaklı haklı (önemli) sebeplerle olağanüstü fesih yoluyla ileriye etkili olarak derhal sona erdirilmesi de mümkündür.

Türk hukukuna göre, koruyucu aileyle yanına yerleştirilen çocuk arasında ne velâyet ne de hısımlık ilişkisi bulunur. Ancak koruyucu aile yanına yerleştirilen çocuk, koruyucu ailenin ev halkı arasında yer alıp ev düzenine tabi olur. Koruyucu aile ise, "ev başkanı" sıfatını haizdir. Bu sebeple koruyucu aile ev düzeninin kurallarını bu çocuğu gözeterek adil biçimde belirlemeli ve özellikle çocuğun dinî inançları bakımından gerekli özgürlükten yararlanmasına olanak sağlamalıdır. Ayrıca koruyucu aile bu çocuğun, kendi gözetim ve bakımında kaldığı süreçte başkalarına verdiği zarardan sorumludur.

Koruyucu aile bakımı geçici olmalıdır. Zira çocuğun şartlar değiştiğinde ana ve babasının yanına dönüşü sağlanmalıdır. Bu sebeple koruyucu aileyle yanına yerleştirilen çocuk arasında, kural olarak, aile hayatı ilişkisi bulunmaz. Bu ilişki, kural olarak, "özel hayata saygı hakkı" kapsamında korunur. Sadece bu ilişkinin uzun süreli olduğu ve çocuğun ana babasıyla kişisel ilişkisi bulunmadığından koruyucu aileyi ana ve baba yerine koyduğu istisnaî hâllerde, bu ilişkinin AİHS ve Anayasa'yla güvence altına alınan "aile hayatına saygı gösterilmesi hakkı" kapsamında korunması mümkündür. Yine kanaatimizce koruyucu aileyle korunmaya ihtiyacı olan çocuk arasında aile benzeri sosyal ilişkinin bulunduğu bu hâllerde, koruyucu aile ve çocuk hukuken birbirinin "yakını" sayılmalıdır. Bu sebeple Türk medenî ve yargılama 
1256 | Dr. Öğr. Üyesi Ayşe Nur KILINÇ

hukukunun "yakın" sayılmaya hukuki sonuç bağladığı hâllerde bu yakınlığın hâkim tarafından dikkate alınması gerekir. 


\section{KAYNAKLAR}

Akçaal, Mehmet: “İsviçre Medenî Kanunu'na Göre Kayyımlık Türleri”, Dokuz Eylül Üniversitesi Hukuk Fakültesi Dergisi, C. 20, Sa. 2, 2018, s. 63-87.

Akıntürk, Turgut / Ateş, Derya: Türk Medenî Hukuku Aile Hukuku İkinci Cilt, 22. Baskı, İstanbul 2020.

Akyol, Şener: Tam Üçüncü Şahıs Yararına Sözleşme, İstanbul 2008.

Akyüz, Emine: "Velâyet, Çocuğun Korunması ve Koruyucu Aile Hizmeti", Koruyucu Aile, Evlat Edinme Hizmetleri ve Ruh Sağlığ1, (Editör: Erol, Neşe), Ankara 2008, s.55-122.

Arslan Öncü, Gülay: Özel Yaşama ve Aile Yaşamına Saygı Hakkı, Anayasa Mahkemesine Bireysel Başvuru El Kitapları Serisi - 8, Avrupa Konseyi, Ocak 2019.

Aydoğdu, Fatih: “Türkiye'de Koruyucu Aile Uygulaması ile İlgili Yapılmış Lisansüstü Tezlerin Değerlendirilmesi", International Social Sciences Studies Journal, C.5, Sa.53, 2019, s.7481-7489.

Aydos, Oğuz Sadık: "Yeni Medeni Kanuna Göre Evlat Edinme”, Gazi Üniversitesi Hukuk Fakültesi Dergisi, C.4, Sa.2, 2000, s.117-141.

Bahadır, Zeynep: Medenî Usul Hukukunda Kısmî Karar, Ankara 2018.

Doğan, Recep: "Bir Koruma Tedbiri Olarak Koruyucu Aile Kurumu ve Koruyucu Aile Yönetmeliği”, Ankara Barosu Dergisi, Sa.2, 2013 s.146-170.

Dural, Mustafa / Öğüz, Tufan / Gümüş, M. Alper: Türk Özel Hukuku Cilt III Aile Hukuku, 15. Baskı, İstanbul 2020.

Elmacı, Davut: "Çocuk Korumada Sistem Yaklaşımı", Prof. Dr. Emine Akyüz'e Armağan Akademisyenlikte Elli Yıl, Ankara 2018, s.171-182.

Erdoğan, İhsan: Borçlar Hukuku Genel Hükümler, 4. Baskı, Ankara 2019.

Eren, Fikret: 6098 Sayılı Türk Borçlar Kanununa Göre Hazırlanmış Borçlar Hukuku Genel Hükümler, 17. Baskı, Ankara 2014.

Erişir, Evrim: Geçici Hukuki Korumanın Temelleri ve İhtiyatî Tedbir Türleri, İstanbul 2013.

Erol, Neşe / Şimşek, Zeynep: “Korunma Gereksinimi Olan Çocuklar; Kurum Bakımı ve Koruyucu Aile Sistemi", Koruyucu Aile, 
Evlat Edinme Hizmetleri ve Ruh Sağlığı, (Editör: Erol, Neşe), Ankara 2008, s.129-167.

Gençcan, Ömer Uğur: Velâyet Hukuku Yargıtay Uygulaması, Bilimsel Açıklama ve En Son İçtihatlar, Ankara 2015.

Grassinger, Gülçin Elçin: Türk Medeni Kanununda Yer Alan Velâyet Hükümleri Kapsamında Küçüğün Kişi Varlığının Korunması İçin Alınacak Tedbirler (MK md. 346, md. 347, md. 348), İstanbul 2009.

Günay İnan, Esra: Aile Hukukunda Geçici Hukukî Himaye Tedbirleri, Ankara 2018.

Gündüz, Olgun: Türkiye'de Çocuklara Yönelik Koruyucu ve Önleyici Politikaları Değerlendirme Çalıştayı Raporu 2017 - Ankara, (Editörler: Kömür, Esra/ Güngör, Ali), Aile ve Sosyal Politikalar Bakanlığ1 Yayın No: 10, Çocuk Hizmetleri Genel Müdürlüğü Yayın No: 05.

Hatemi / Gökyayla: Borçlar Hukuku Genel Bölüm, İstanbul 2011.

Hatemi, Hüseyin / Kalkan Oğuztürk, Burcu: Aile Hukuku, 6. Baskı, İstanbul 2018.

İnan, Ali Naim: “Çocuk Hukuku Bakımından Korunma Kararı, Koruma ve Emniyet Tedbiri Kavramları", Prof. Dr. M. Şakir Berki'ye Armağan, Selçuk Üniversitesi Hukuk Fakültesi Dergisi, C.5, Sa.1-2, 1996, s.1-21.

Kanadoğlu, Korkut: "Evlilik ve Ailenin Anayasal Korunması", Anayasa Mahkemesinin Medeni Hukuka İlişkin Kararlarının Değerlendirilmesi Sempozyumu (21 Mayıs 2012), İstanbul 2013, s.93-106.

Karataş, Ceylan Pınar: "Aile Yanında Hizmet", Sosyal Hizmet, Sosyal Hizmet Uzmanları Derneği Yayını, 2018/I, Ocak Haziran 2018, s.64-72.

Karataş, Kasım: “Türkiye'de Çocuk Koruma Sistemi ve Koruyucu Aile Uygulamaları Üzerine Bir Değerlendirme", Koruyucu Aile, Evlat Edinme Hizmetleri ve Ruh Sağlığı, (Editör: Erol, Neşe), Ankara 2008, s. 41-54, (Kısaltılmışı: Karataş, Koruma Sistemi). 
Karatay, Abdullah: “Türkiye'de Koruyucu Aile: Kökenleri, Gelişimi ve Bugünü", Üsküdar Üniversitesi Sosyal Bilimler Dergisi, Sa.5, 2017, s.389-427.

Keskin, A. Dilşad: “Bölünmüş Annelik ve Ana Yönünden Soybağının Reddi", Çankaya Üniversitesi Hukuk Fakültesi Dergisi, C.5, Sa.1-2, 2020, s.1989-2016.

Kilkelly, Ursula: Özel Hayata ve Aile Hayatına Sayg1 Gösterilmesi Hakkı, Avrupa İnsan Hakları Sözleşmesi'nin 8. Maddesi'nin uygulanmasına ilişkin kılavuz, İnsan Hakları El Kitapları, No.1, Ankara 2003.

Konanç, Esin: "Türk Hukuk Sisteminde Çocuğun Korunması", Türkiye'de Çocuğun Durumu, T.C. Başbakanlık Devlet Planlama Teşkilatı Sosyal Planlama Başkanlığ1 Kitap No:103, Ankara 1989, s.3-33.

Koşar, Nesrin G.: “Türkiye'de Çocuk Refahı Hizmetlerinin Dünü", Koruyucu Aile, Evlat Edinme Hizmetleri ve Ruh Sağlı̆̆1, (Editör: Erol, Neşe), Ankara 2008, s.7-15.

Özdemir, Hayrunnisa / Ruhi, A. Cemal: Çocuk Hukuku (Ders Kitabı), 3. Baskı, İstanbul 2019.

Özdemir Uluç, Fatma: Psiko-Sosyal ve Hukuksal Açıdan Koruyucu Aile Bakımı, Ankara 1997.

Öztan, Bilge: Aile Hukuku, 6. Baskı, Ankara 2015.

Seliçi, Özer: Borçlar Kanununa Göre Sözleşmeden Doğan Sürekli Borç İlişkilerinin Sona Ermesi, İstanbul 1976.

Serdar, İlknur: "Koruyucu Aile", Prof. Dr. Seyfullah Edis'e Armağan, İzmir 2000, s.467-508.

Tanrıbilir, Feriha Bilge: Çocuk Haklarının Uluslararası Korunması ve Koruma Mekanizmaları, Ankara 2011.

Tanrıver, Süha: Türk Aile Mahkemeleri, Ankara 2014.

Tezel, Zeynep / Demirel, Barış / Kaya, Zühal Şahin: “Ailelerin Koruyucu Aile Olmaya Karar Vermelerinde Etkili Olan Etmenler ile Koruyucu Aile Olmanin Anlam ve Önemi", Sosyal ve Beşeri Bilimler Araştırmaları Dergisi, C.19, Sa.43, 2018, s.15-36.

Usta, Sevgi: Çocuk Hakları ve Velayet, İstanbul 2012 (Kısaltılmışı: Usta, Çocuk Hakları). 
Usta Sayıta, Sevgi: Türk Hukukunda Çocuğun Koruyucu Aile (Kişi) Yanına Yerleştirilmesi, İstanbul 1996.

Ünal, Mehmet: Türk Medenî Hukukunda Aile Başkanının Sorumluluğu, Ankara 1979.

Üstüner, Seval / Erol, Neşe / Şimşek, Zeynep: “Koruyucu Aile Bakımı Altındaki Çocukların Davranış ve Duygusal Sorunları", Çocuk ve Gençlik Ruh Sağlığı Dergisi, C.12, Sa.3, 2005, s.130-140.

Yazıc1, Ergün: “Türkiye'de Çocuk Koruma Sistemi ve Koruyucu Aile Bakım Yönteminde Yeni Yaklaşımlar", Çankırı Karatekin Üniversitesi İktisadi ve İdari Bilimler Fakültesi Dergisi, C.4, Sa.2, 2014, s.247-270.

Zevkliler, Aydın: “Türk Hukukunda Korunmaya Muhtaç Çocuklar", Ankara Üniversitesi Hukuk Fakültesi Dergisi, C.25, Sa.1, 1968, s.173-236.

Çocuk Haklarıyla İlgili Avrupa Hukuku El Kitabı, Avrupa Birliği Temel Haklar Kurumu ve Avrupa Konseyi, 2015, http://www.cocukgozlemevi.org/aihm/yayinlar, s.e.t. 12.05.2020.

Birleşmiş Milletler Çocuk Haklarına Dair Sözleşme ve İhtiyari Protokoller, Usûl Kuralları ile Çocuk Hakları Komitesi Genel Yorumları, UNICEF, Haziran 2019, https://www.unicef.org/turkey/, s.e.t. 09.05.2020 (Kısaltılmışı:

Çocuk Hakları Komitesi Genel Yorumları).

https://www.ailevecalisma.gov.tr/tr-tr/istatistikler/aile-ve-sosyal-

politikalar-alanindaki-istatistikler/cocuk-hizmetleri-

istatistikleri/, s.e.t. 15.04.2010.

https://www.ailevecalisma.gov.tr/tr-tr/haberler/bakan-selcuk-koruyucuaile-temelli-cocuk-koruma-sistemi-calistayi-25-26-subat-taduzenlenecek/, s.e.t. 06.05.2020.

https://www.ohchr.org/Documents/ProfessionalInterest/crc.pdf, s.e.t. 22.04.2020.

Yargitay kararları için bkz. https://karararama.yargitay.gov.tr/, s.e.t. 21.05.2020. 
Türk Hukukunda Koruyucu Aile Sözleşmesi ve Koruyucu Aile ile Çocuk... | 1261

Kamu Denetçiliği Kurumu kararı için bkz. https://www.ombudsman.gov.tr/2016-yili-kararlari/index.html, s.e.t. 21.05 .2020 . 